\title{
Ceramic Types from Late Prehistoric Sites along the East Fork of the Trinity River
}

Wilson W. Crook III

Houston Archeological Society

Mark D. Houghston

Brazos Gas Company

Follow this and additional works at: https://scholarworks.sfasu.edu/ita

Part of the American Material Culture Commons, Archaeological Anthropology Commons, Environmental Studies Commons, Other American Studies Commons, Other Arts and Humanities Commons, Other History of Art, Architecture, and Archaeology Commons, and the United States History Commons

Tell us how this article helped you.

This Article is brought to you for free and open access by the Center for Regional Heritage Research at SFA ScholarWorks. It has been accepted for inclusion in Index of Texas Archaeology: Open Access Gray Literature from the Lone Star State by an authorized editor of SFA ScholarWorks. For more information, please contact cdsscholarworks@sfasu.edu. 


\section{Ceramic Types from Late Prehistoric Sites along the East Fork of the Trinity River}

\section{Licensing Statement}

Reproduction, posting, transmission, or other distribution or use of the Journal volume, individual article or any portion of the material therein, in any medium, is permitted strictly for personal, non-commercial purposes via a personal-use exemption under a Creative Commons license granted by JTAH.org, Inc. This license exemption requires, as a condition of its granted permission, proper credit be attributed to JTAH.org as copyright holder (e.g., Journal of Texas Archeology and History.org (C 2015). No part of this publication may be reproduced, posted, transmitted, or otherwise utilized or distributed in any form by any means or method for commercial purposes without the express written consent of the Publisher.

Inquiries should be addressed to JTAH Publisher, Suite 307, Box 361, 5114 Balcones Woods Drive, Austin, Texas, 78759.

The Journal of Texas Archeology and History.org is an organization dedicated to furthering research, education and public outreach in the fields of archeology and history concerning Texas and its bordering states of Louisiana, Arkansas, Oklahoma, New Mexico and Northern Mexico; a region we call the "Texas Borderlands." The J.T.A.H. is collaborating with the Index of Texas Archaeology and S.F.A.S.U. to distribute their publication library to the general public via free and open-access channels. Visit www.JTAH.org to submit an article. 


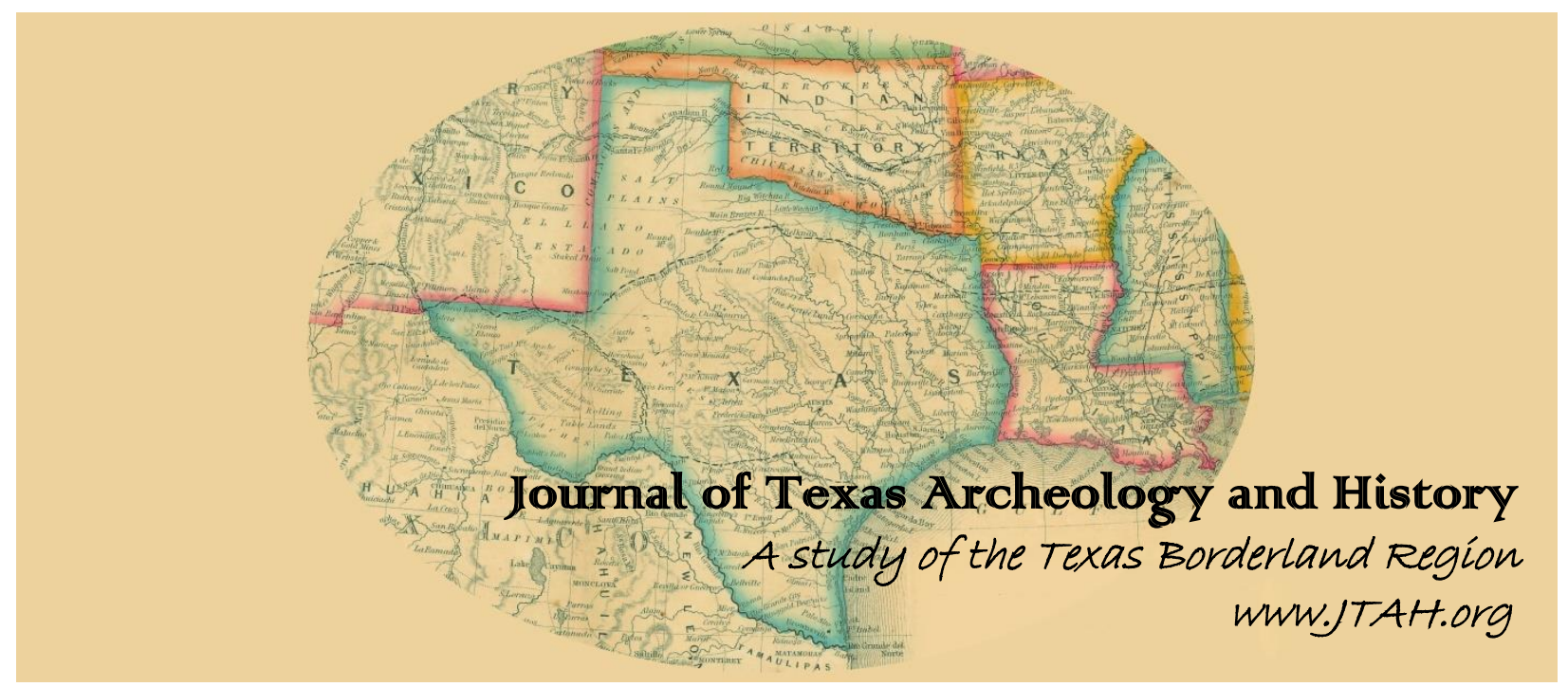

\section{Article Title: CERAMIC TYPES FROM LATE PREHISTORIC SITES ALONG THE EAST FORK OF THE TRINITY RIVER Author(s): $\quad$ Wilson W. Crook, III and Mark D. Hughston}

Original Source: J.T.A.H. Volume 2 (2015), Article 2, pp. 17 - 44; online 16 February 2015

Recommended Citation: Crook, III, Wilson W. and Mark D. Hughston; "Ceramic Types from Late Prehistoric Sites Along the East Fork of the Trinity River", (2015), Journal of Texas Archeology and History Volume 2 (2015), pp. 17 - 44.

Copyright $(C 2015$ by Journal of Texas Archeology and History.org, Inc. All rights reserved. Online/Digital publication: ISSN 2334-1874

The online, digital and print versions of the publication "Journal of Texas Archeology and History" are published by Journal of Texas Archeology and History.org, Inc., a Texas nonprofit IRC Section 501(c)(3) corporation.

Reproduction, posting, transmission, or other distribution or use of the Journal volume, individual article or any portion of the material therein, in any medium, is permitted strictly for personal, non-commercial purposes via a personal-use exemption under a Creative Commons license granted by JTAH.org, Inc. This license exemption requires, as a condition of its granted permission, proper credit be attributed to JTAH.org as copyright holder (e.g., Journal of Texas Archeology and History.org (C) 2015). No part of this publication may be reproduced, posted, transmitted, or otherwise utilized or distributed in any form by any means or method for commercial purposes without the express written consent of the Publisher. Inquiries should be addressed to JTAH Publisher, Suite 307, Box 361, 5114 Balcones Woods Drive, Austin, Texas, 78759.

The Journal of Texas Archeology and History.org is an organization dedicated to furthering research, education and public outreach in the fields of archeology and history concerning Texas and its bordering states of Louisiana, Arkansas, Oklahoma, New Mexico and Northern Mexico; a region we call the "Texas Borderlands." The J.T.A.H. is collaborating with the Index of Texas Archaeology and S.F.A.S.U. to distribute their publication library to the general public via free and open-access channels. Visit www.JTAH.org to submit an article. 


\title{
CERAMIC TYPES FROM LATE PREHISTORIC SITES ALONG THE EAST FORK OF THE TRINITY RIVER
}

\author{
Wilson W. Crook, III and Mark D. Hughston
}

\begin{abstract}
Ceramics are one of the key diagnostic artifacts that define the Late Prehistoric culture of the peoples that lived along the East Fork of the Trinity and its tributaries. We are completing a 42-year re-evaluation of the Late Prehistoric period of the area and have studied nearly 32,000 artifacts, of which over 10,200 are ceramic sherds. From this study, 20 distinct ceramic types have been recognized. Plain ware, both shell-tempered and sandy paste/grog-tempered, are the predominant ceramic types present, comprising over 90 percent of the total ceramic assemblage. While there is little direct evidence for indigenous manufacture, the abundance of these types suggests they were produced locally. Lesser quantities of decorated ware of distinct Caddo ceramic types from the Red River and East Texas suggest they are likely the product of exchange. There is also a small amount of Puebloan material indicative of a longer distance exchange.
\end{abstract}

\section{INTRODUCTION}

Numerous sites of the Late Prehistoric period occur along the East Fork of the Trinity River and its tributaries in a roughly north-south corridor from Collin County in the north to northwestern Kaufman County, some $70 \mathrm{~km}$ to the south. Over 50 sites have been identified that share similar cultural materials (Figure 1). Of these, we have arbitrarily designated 20 as "major sites" based on their aerial size ( $>0.5$ hectares) and number of artifacts recovered $(>100)$, with the others being smaller, seasonal campsites. The observed artifact assemblage in all of these sites is very homogeneous and consistent with the Late Prehistoric period along the East Fork as initially characterized by Stephenson $(1949 b, 1952)$ and subsequently redefined by Lynott (1975a, 1975b), Crook (1987, 1989, 2007a), and Crook and Hughston (2008, 2009). The age of the Late Prehistoric period along the East Fork has been radiocarbon-dated from ca. A.D. 700 to A.D. 1600 (Valastro et al. 1967; Marmaduke 1975; Lynott 1975a, 1978; Crook and Hughston n.d., in press).

The sites along the East Fork and its tributaries differ in terms of cultural material from Late Prehistoric sites to the west along the Elm Fork of the Trinity, to the east in the Sulphur River drainage, as well as farther south along the main branch of the Trinity (Figure 2). Sites along the Elm Fork have a significantly higher percentage of triangular arrow points (Fresno, Harrell, and Washita types) and have a larger proportion of shell-tempered ceramics, both of which are more characteristic of the Henrietta phase of the southern Great Plains (Stephenson 1949a; Prikryl 1990). Sites east of the East Fork in East Texas belong to the Caddo tradition (Perttula 1992).

\footnotetext{
JOURNAL OF TEXAS ARCHEOLOGY AND HISTORY

VOLUME 2:17-44

THE ONLINE PUBLICATION JOURNAL OF TEXAS ARCHEOLOGY AND HISTORY (ISSN 2334-1874)

IS PUBLISHED BY JOURNAL OF TEXAS ARCHEOLOGY AND HISTORY.ORG. COPYRIGHT (C) 2015 JOURNAL OF TEXAS ARCHEOLOGY AND HistORY.ORG. ALL RIGHTS RESERVED.
} 


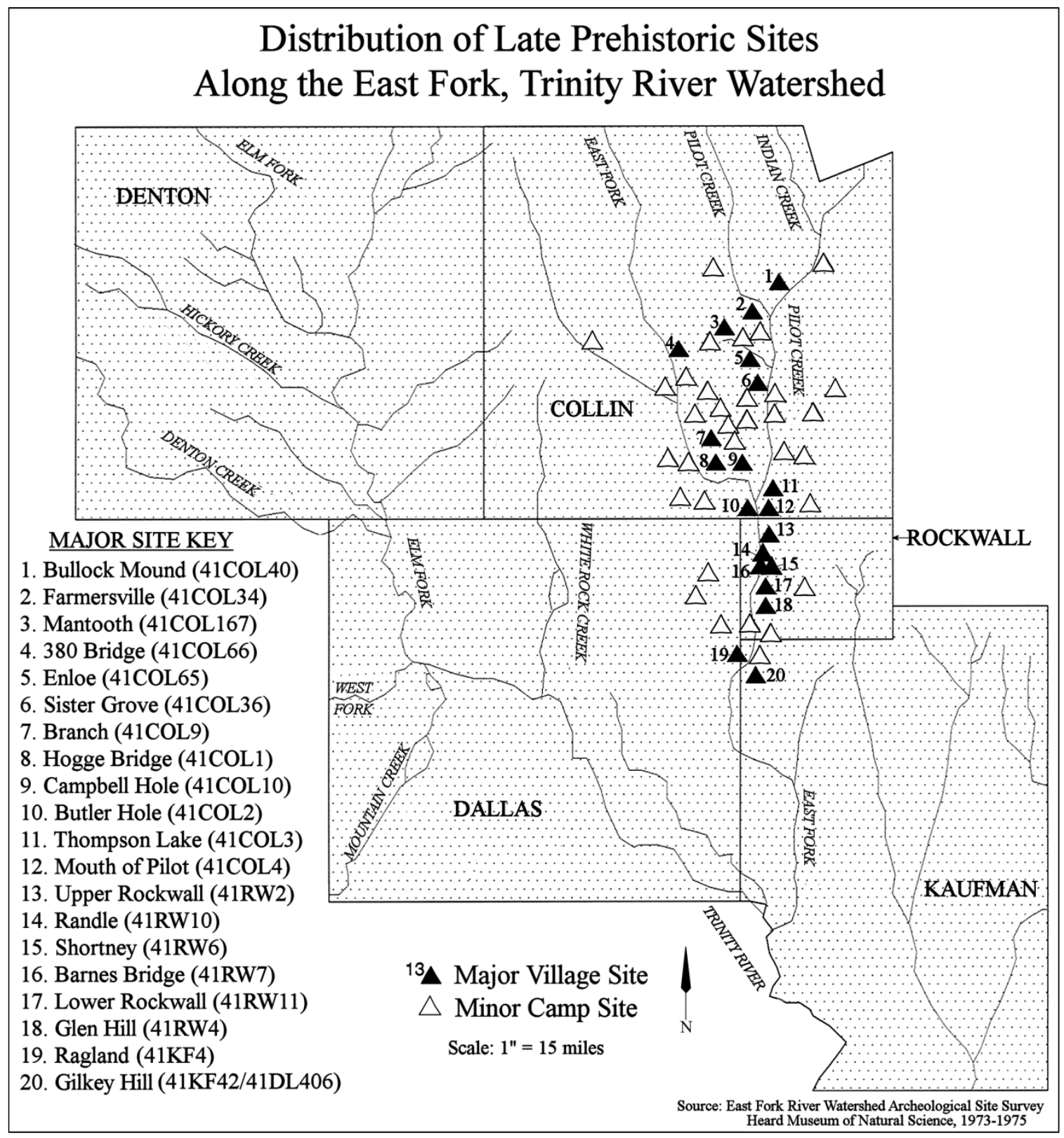

Figure 1. Distribution of Late Prehistoric sites along the East Fork of the Trinity River and its tributaries. Major sites are identified by solid black triangles and identified by name; minor seasonal campsites are shown as unfilled triangles.

Likewise, sites to the south along Richland Creek, such as Bird Point Island (41FT201) and Adams Ranch (41NV177), are characterized by a number of traits that differ from those characteristic of the East Fork Late Prehistoric. Chief among these are: (1) different shaped house structures, (2) extensive use of Psoralea, the Prairie Turnip, absent in archeological deposits along the East Fork, (3) the virtual absence of any shell-tempered ceramics which comprise nearly 50 percent of East Fork ceramics, (4) the occurrence of Hayes and Cuney points and the lack of Catahoula and Fresno points, (5) the occurrence of different utilitarian tools such as the Bristol biface and the complete absence of sub-triangular scrapers such as the "East Fork Biface" (Crook and Hughston 2007), and (6) the absence of tools made from worked mussel shell. Moreover, while both the Richland Creek and the larger East Fork sites have a distinctive rim-and-pit structure (the so-called 


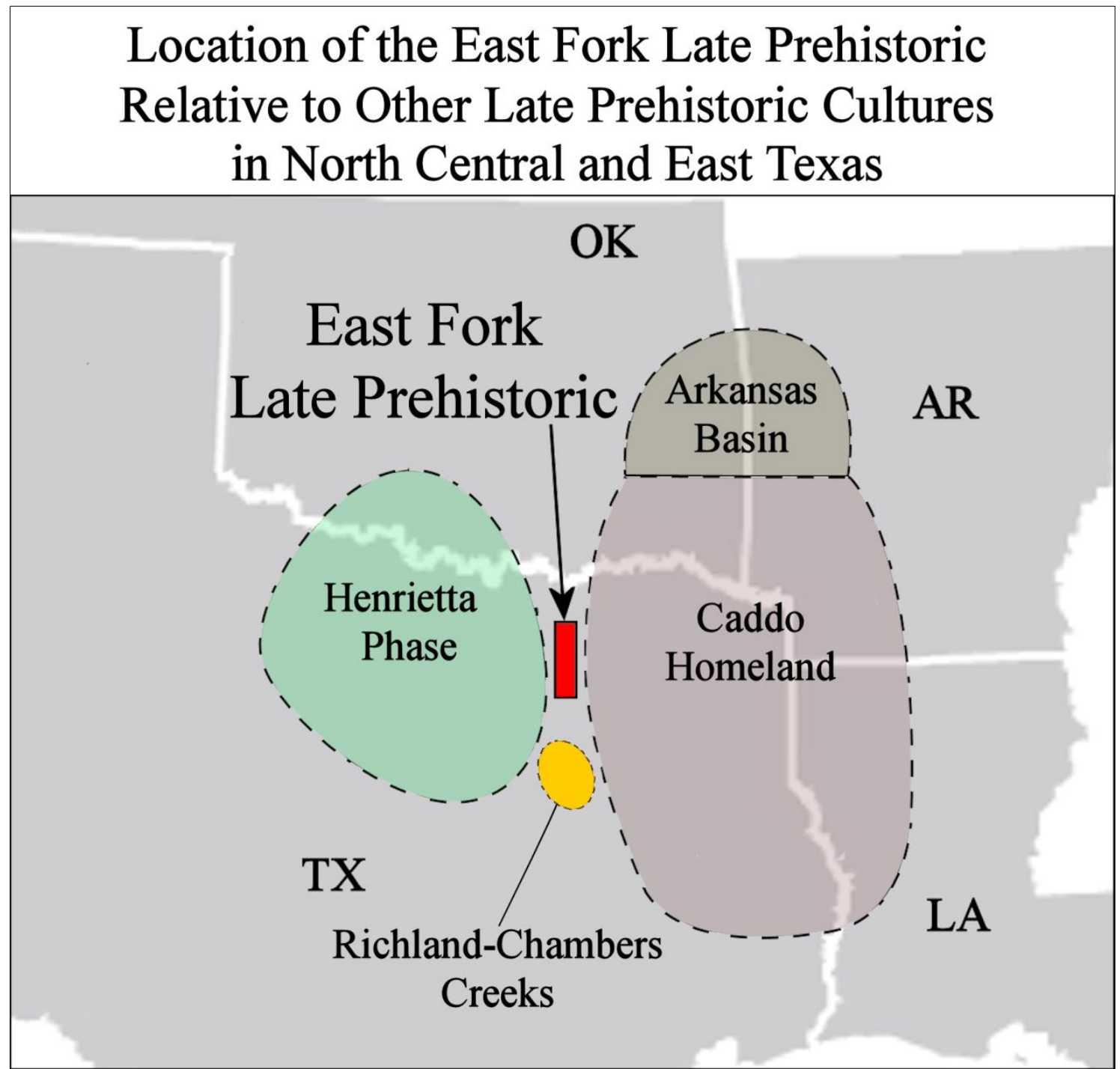

Figure 2. Location of the East Fork Late Prehistoric relative to other Late Prehistoric cultures in North Central and East Texas.

"Wylie Pits"), their use appears to be very different. Bruseth and Martin (1987) found that the pit structures at Bird Point Island and Adams Ranch were created in Archaic times and changed functions from a cemetery in the Late Archaic to a roasting pit and then to trash pits in the Late Prehistoric. The Archaic burials always occur in the center of the pits, not in the rims. The rim-and-pit structures along the East Fork all date to the Late Prehistoric and were consistently used as roasting pits, with the rims being reserved for burial of high status individuals (Lynott 1975a; Crook and Hughston 2008). Thus, while having a material culture that shares traits with their surrounding neighbors, the Late Prehistoric inhabitants of the East Fork appear to have had a unique set of cultural traits that sets them distinctly apart.

Ceramics are one of the key diagnostic features that were used initially to define the Late Prehistoric culture of the peoples that lived along the East Fork of the Trinity River and its tributaries (Stephenson 1952). 
However, there is very little evidence in the archeological record that the ceramics found in East Fork sites was manufactured locally (Stephenson 1952; Ross 1966; Lynott 1975; Crook and Hughston 2008). The only such direct evidence for local manufacture is a single shell-tempered plain bowl from the Upper Farmersville (41COL34) site that fell apart during firing and was tossed into a trash pit (Crook and Hughston 1986). As a result, previous researchers have concluded that the majority, if not all, of the ceramics found across the district appear to be present as a result of exchange (the term "exchange" is used here as a proxy for all forms of trade and exchange interaction) (Harris 1948; Stephenson 1952; Ross 1966; Lorrain and Hoffrichter 1968; Lynott 1975a).

We are currently in the process of completing a 42-year re-evaluation of the Late Prehistoric period of the East Fork. As part of this study, we have examined all the collections from previous excavations in the area as well as those of most local avocational collectors. To date, this study comprises nearly 32,000 artifacts, of which over 10,200 are ceramic sherds. With regard to the ceramic assemblages from different East Fork sites, each sherd has been categorized with regard to the following: plain or decorated, the type of decoration present, the type of temper used, surface color, texture, the color and nature of the paste, the presence of slip, etc. Very few sherds were observed that have compound decorative elements, such as incised-punctated. For the sake of simplicity, those sherds that had dual elements have been categorized based on which element was the dominant form of decoration. Typologies used follow those defined in Suhm and Krieger (1954) and Suhm and Jelks (1962). We also used the typological identifications made by certain previous researchers such as R. K. "King" Harris.

A select number of "grit"-tempered sherds $(\mathrm{n}=504)$ were viewed under a binocular microscope (20-60x) to determine if the "grit" (sand) was inherent to the clay formation or was a later added product. In all cases, there was no evidence that any sand grains had been pounded or ground. As the local clays in the East Fork area are all sandy in nature (Hanson and Wheeler 1969; Pringle 1977; Coffee et al. 1980), we have concluded that any locally manufactured grit-tempered ceramics on the East Fork used the indigenous clay sources without the need for adding any sand. As a result, for the purposes of this study, the term "grit" has been replaced by "sandy paste." To better quantify the character of ceramic pastes, a more detailed petrographic study of East Fork ceramics is planned for the future. In addition, 30 representative sherds of a number of different types from East Fork sites have been submitted for Instrumental Neutron Activation Analysis to further assess the likelihood of local ceramic manufacture.

From this study, four major groups of ceramic vessel manufacture have been identified: (1) a plain, sandy paste-grog-tempered ware of the type found in Fourche Maline and Fourche Maline-like cultures to the northeast along the Red River in East Texas, (2) a shell-tempered plain ware similar to that found to the west of the East Fork in the Henrietta phase of the southern Great Plains, (3) decorated and plain ceramics of known Caddo types from both along the Red River as well as from the Upper Neches, Angelina, and Sabine River basins, and (4) a small amount of distinctly Puebloan ware, that, based on typology, mostly originates in north central New Mexico. This article records for the first time the entire known ceramic assemblages of the East Fork and further discusses the possible evidence, based on these ceramic assemblages, of contact between the Late Prehistoric populations living in the Upper Trinity River basin, those in the Plains to the west as well as the Caddo peoples to the east-southeast. 


\section{EAST FORK CERAMIC ASSEMBLAGES}

As part of our re-evaluation of the East Fork Late Prehistoric, the curated collections from all of the previous major excavations along the East Fork have been extensively studied. This includes the work of Stephenson (1952) from the Hogge Bridge (41COL1), Branch (41COL9) and Campbell Hole (41COL10) sites, those from Ross' (1966) excavation of the Upper Rockwall (41RW2) site, Lorrain and Hoffrichter's (1968) excavation of Lower Rockwall (41RW1), Dawson and Sullivan's (1969) work at the Upper Farmersville site (41COL34), and Lynott's (1975a) excavation of the Sister Grove Creek (41COL36) site. In addition, we have studied the private collections of R. K. "King" Harris in the Smithsonian Institution, as well as those of the members of the Dallas Archeological Society (Rex Housewright, Lester Wilson, J. B. Sollberger, Wilson "Bill" Crook, Jr., Bobby Vance and others) who did much of the early work on the East Fork sites. The results of our own excavations are also a significant part of this work (Crook 1985, 2007a, 2007b, 2013; Crook and Hughston 1986, 2008, 2009; Crook and Perttula 2008).

Table 1 includes the total ceramic assemblage for the Late Prehistoric sites of the East Fork, both by site and by major ceramic type. As can be seen, plain ceramic types, both shell-tempered and sandy paste-grogtempered ware, comprise 84 percent of the ceramic assemblages. Shell-tempered plain ceramics (primarily Nocona Plain) represent almost half of the recovered sherds. Only slightly less common is sandy paste-grogtempered plain ceramics. The type Williams Plain as well as various un-named sandy paste-grog-tempered plain ceramics comprise this assemblage. Slipped Sanders Plain ceramics account for 7 percent of the ceramic sherds, incised ceramic sherds of a number of types represent 4 percent, with punctated ( 3 percent), engraved ( 1 engraved), and brushed (1 percent) sherds comprising most of the remainder of the assemblage. A small amount of Puebloan trade ware ( 29 sherds) has been recovered from four sites on the East Fork.

As noted, the individual ceramic types that make up this assemblage can be divided into four general wares. Each of these will be discussed below, including the specific types that have been identified within the wares. All typologies used follow those defined in Suhm and Krieger (1954) and Suhm and Jelks (1962), except for Sanders Plain, which follows the revised typological definition of Brown (1996).

\section{Sandy Paste/Grog-Tempered Plain Ware}

The most common sandy paste grog-tempered ceramic type is Williams Plain. A total of 3,642 sherds have been recorded in the East Fork assemblages, representing 36 percent of all East Fork ceramics (see Table 1). Williams Plain has been found in all of the larger sites and in many of the smaller campsites. Williams Plain sherds occur in a wide range of colors ranging from buff to tan to gray-brown to brown to black and most shades in between. Temper also includes a wide range of materials but is typically grog and bone is rarely used. The latter, when present, is characterized by large fragments often up to $5 \mathrm{~mm}$ in size. Sherds are typically very thick, and vessel bases in excess of $20 \mathrm{~mm}$ in thickness are not uncommon. Vessels of this type are almost exclusively flat-bottomed, flower pot-shaped bowls and jars (Schambach 2002). Figure 3 (upper right) shows a typical sherd of Williams Plain from the Mantooth site (41COL167). 
Table 1. East Fork Late Prehistoric ceramic sherd totals by site.

\begin{tabular}{|c|c|c|c|c|c|c|c|c|c|}
\hline Site Name & $\begin{array}{l}\text { Plain Shell } \\
\text { Temper }\end{array}$ & $\begin{array}{l}\text { Plain } \\
\text { SP Grog } \\
\text { Temper }\end{array}$ & $\begin{array}{l}\text { Slipped } \\
\text { SP Grog } \\
\text { Temper }\end{array}$ & 1 & $\mathbf{P}$ & E & B & $\begin{array}{l}\text { Puebloan } \\
\text { Trade Ware }\end{array}$ & $\mathbf{N}$ \\
\hline Hogge Bridge & 230 & 76 & 89 & 15 & 56 & 1 & 1 & - & 468 \\
\hline Butler Hole & 48 & 30 & 14 & 24 & 26 & - & - & - & 142 \\
\hline Thompson Lake & 27 & 16 & 6 & 2 & 1 & - & 1 & - & 53 \\
\hline Mouth of Pilot & 19 & 11 & 4 & 2 & - & - & 2 & - & 38 \\
\hline Branch & 627 & 313 & 38 & 35 & 12 & 9 & 6 & 4 & 1,044 \\
\hline Campbell Hole & 29 & 17 & 11 & 1 & 2 & - & - & - & 60 \\
\hline Upper Farmsville & 691 & 205 & 84 & 39 & 18 & 16 & 35 & 11 & 1,099 \\
\hline Sister Grove Creek & 72 & 33 & - & 22 & 1 & - & - & - & 128 \\
\hline Enloe & 65 & - & 11 & - & - & 6 & - & - & 82 \\
\hline 380 Bridge & 83 & 1 & 21 & - & 2 & - & - & - & 107 \\
\hline Mantooth & 25 & 20 & 12 & 2 & 3 & 1 & 1 & - & 64 \\
\hline Lower Rockwall & 1,281 & 1,300 & 292 & 99 & 80 & 38 & 42 & 1 & 3,133 \\
\hline Upper Rockwall & 396 & 357 & 66 & 79 & 29 & 4 & 20 & - & 951 \\
\hline Glen Hill & 659 & 706 & 8 & 83 & 28 & - & 6 & - & 1,560 \\
\hline Shortney & 36 & 7 & 4 & 4 & - & - & - & - & 51 \\
\hline Barnes Bridge & 1 & 14 & - & - & - & - & - & - & 15 \\
\hline Randle & 70 & 119 & 41 & 7 & 2 & - & - & - & 239 \\
\hline Ragland & 35 & 132 & 4 & 4 & 2 & 1 & 3 & - & 181 \\
\hline Gilkey Hill & 290 & 183 & - & 6 & 5 & 2 & 8 & - & 494 \\
\hline 38 Small Sites & 187 & 102 & - & - & 7 & - & - & 12 & 308 \\
\hline Totals & 4,871 & 3,642 & 775 & 424 & 274 & 78 & 125 & 28 & 10,217 \\
\hline Percentage & $48 \%$ & $36 \%$ & $7 \%$ & $4 \%$ & $3 \%$ & $1 \%$ & $1 \%$ & $<1 \%$ & \\
\hline
\end{tabular}

$\mathrm{SP}=$ sandy paste; $\mathrm{I}=$ incised; $\mathrm{P}=$ punctated; $\mathrm{E}=$ engraved; $\mathrm{B}=$ brushed

Williams Plain is widely recognized as one of the diagnostic artifacts of the Woodland Fourche Maline culture of southeastern Oklahoma and southwestern Arkansas (Schambach 1998, 2001). While the Fourche Maline culture is suggested by Schambach $(1995,2002)$ to have extended into Northeast Texas as far as the George C. Davis (41CE19) site, it is not universally recognized as such. Story (1990) referred to this period as the Early Ceramic Stage in East Texas, representing the general time span between ca. 200 B.C. and A.D. 800 when ceramics are first adopted and produced in the region; most Northeast Texas archeologists currently use the Woodland period terminology.

In Northeast Texas, the Woodland period follows the end of the Archaic period and precedes the development of the post-A.D. 800 Caddo tradition (Cliff 1998). A similar culture is present in sites along the East Fork. While many of the East Fork sites are on land that has been extensively cultivated, a few sites with stratigraphically intact areas have been excavated. These include the Sister Grove Creek site (Lynott 1975a), the Enloe site (41COL65) (Crook 1989), the Branch site (Crook 2007a), and part of the Upper Farmersville site (Crook 2009; Crook and Hughston 2009). These excavations have shown that while ceramics are typically pene-contemporaneous with arrow points, it is also present in archeological deposits that predate the introduction of the bow and arrow and concurrent with the use of dart points, primarily the Gary point. The only ceramic type present at these earlier horizons is Williams Plain. As such, Williams Plain is seen as the 


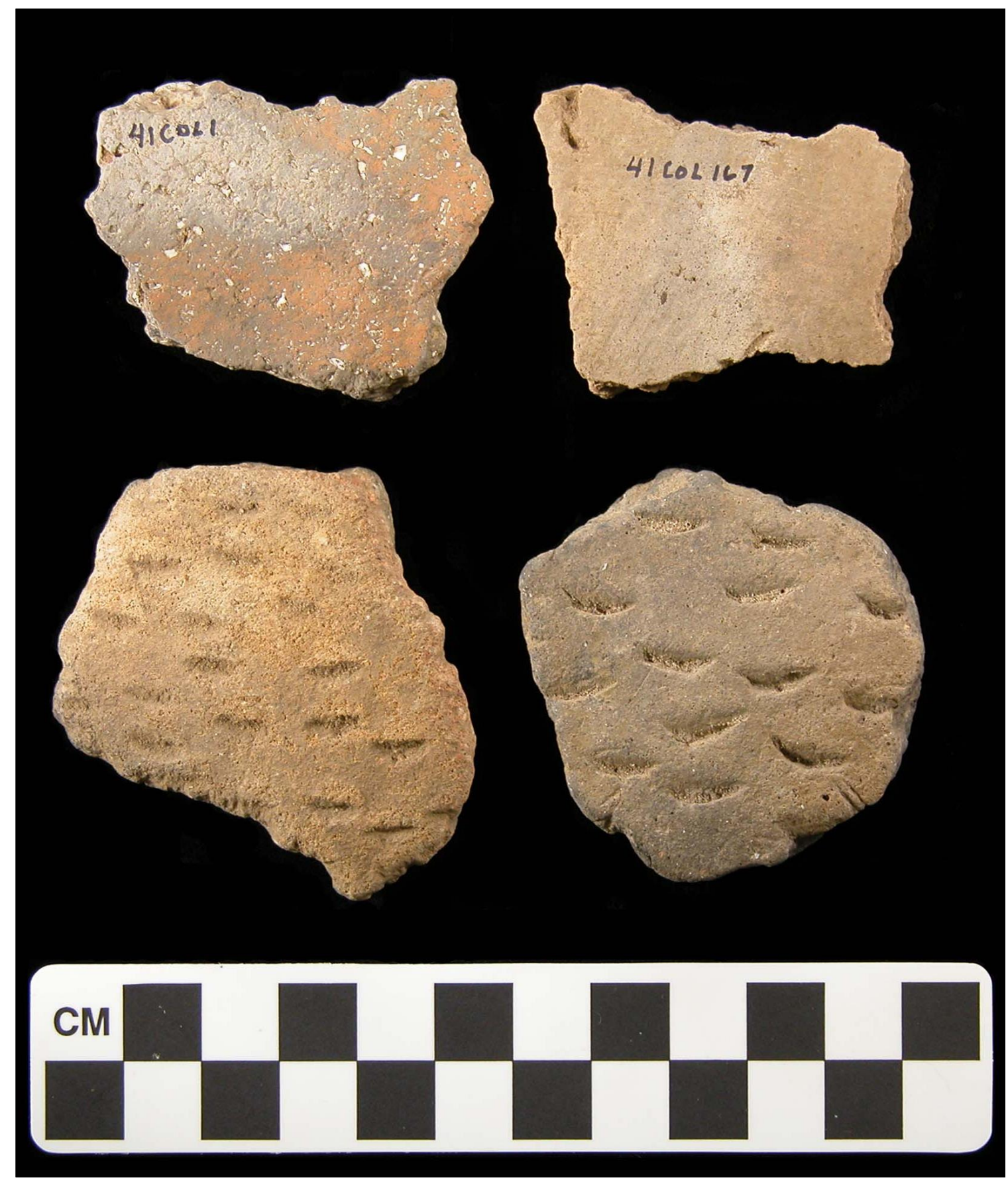

Figure 3. Williams Plain (upper right) from the Mantooth (41COL167) site, Collin County, Texas. Note the difference between Williams Plain and the shell-tempered Nocona Plain (upper left). Bottom Row: Monkstown Fingernail Impressed sherds from the Branch (41COL9) site, Collin County.

earliest ceramic ware on the East Fork. Williams Plain was continued to be made until at least A.D. 1200 in Northeast Texas Caddo sites, which may help explain its abundance in the region (Timothy K. Perttula, personal communication, 2014). 


\section{Shell-Tempered Plain Ware}

While Williams Plain is the most common sandy paste grog-tempered ceramic along the East Fork, the single most common ceramic type is shell-tempered Nocona Plain (see Table 1), comprising nearly 50 percent of all the ceramics. Nocona Plain is a diagnostic ceramic type on sites of the Henrietta phase in the southern Great Plains to the west (the Henrietta Phase extends eastward as far as the West and Elm Forks of the Trinity 60 km west of the East Fork) (Prikryl 1990; Brack 1999; Bell and Brooks 2001). Sherd color ranges from buff to all shades of red-brown to brown to black. Vessels are limited to large, flat-bottomed bowls and jars that are relatively thick and crudely made with interior and exterior surfaces only roughly smoothed. Nocona Plain is characterized by its distinctive shell temper (typically from local riverine mussel shells) that is almost always plainly visible on the surface (see Figure 3, upper left). Occasionally with burial and time the shell temper on the surface of sherds has been leached, leaving large, irregular holes on the exposed surfaces. The base of a typical flat-bottomed Nocona Plain bowl from the East Fork is shown in Figure 4.

While it remains uncertain how much of the Nocona Plain found along the East Fork is of local production, at least one large bowl was discovered at the Upper Farmersville site that is clearly an attempt at local manufacture (Crook and Hughston 1986) (Figure 5). The bowl was found to be over-fired on one side and under-fired on the opposite side. Large frothy bubbles were present in parts of the over-fired side while the opposite side was in a very friable condition not unlike sun-baked clay. The vessel was found in an area of site where trash (burned bone, lithic debitage) was buried, obviously discarded after its failure to fire properly. Because no other definitive evidence of local manufacture has been found in the region, the remainder of the Nocona Plain ceramics has been assumed by previous researchers to have been imported via trade (Stephenson 1952; Ross 1966; Lorrain and Hoffrichter 1968; Lynott 1975a). However, the large number of Nocona Plain sherds found on East Fork sites (see Table 1) would suggest that most of this type was manufactured locally.

Recently a nearly complete shell-tempered vessel was recovered from the Sister Grove Creek site in Collin County. The vessel is a small jar, $95.5 \mathrm{~mm}$ in height. It has a rounded base (approximately $71.2 \mathrm{~mm}$ across) with a gently rounded body that slopes inward near the base of the rim and then flares outward (Figure 6). Two strap handles were once present, one having probably been broken during use given the weathered nature of the break. The remaining handle is curved, with a length is $21.8 \mathrm{~mm}$ and a width is $20.0 \mathrm{~mm}$; thickness of the handle is $4.0 \mathrm{~mm}$. The vessel is plain with no exterior decoration other than prominent lip notching every $7-8 \mathrm{~mm}$ around the edges of the rim.

Wall thickness of the vessel varies from $5.0 \mathrm{~mm}$ near the rim to $6.0-6.8 \mathrm{~mm}$ on the main part of the body to $7.5 \mathrm{~mm}$ at the base. These thickness data suggest that the vessel appears to have been built from the base upwards to the rim (cf. Krause 2007). It is tempered with shell and finely-crushed grog and has a compact clay paste. The color of the vessel is quite variable, primarily due to extensive fire mottling, ranging from very pale brown (10YR 7/4), gray-brown (10Y 3/1), greenish-gray (5GY 5/1), to gray-brown (2.5Y 5/2). Cores of the sherds are darker than the surfaces, suggesting the vessel was fired in a low oxygen or reducing environment, and then pulled from the fire to cool. Both the interior and exterior surfaces of the jar are highly smoothed, almost polished in surface treatment. 


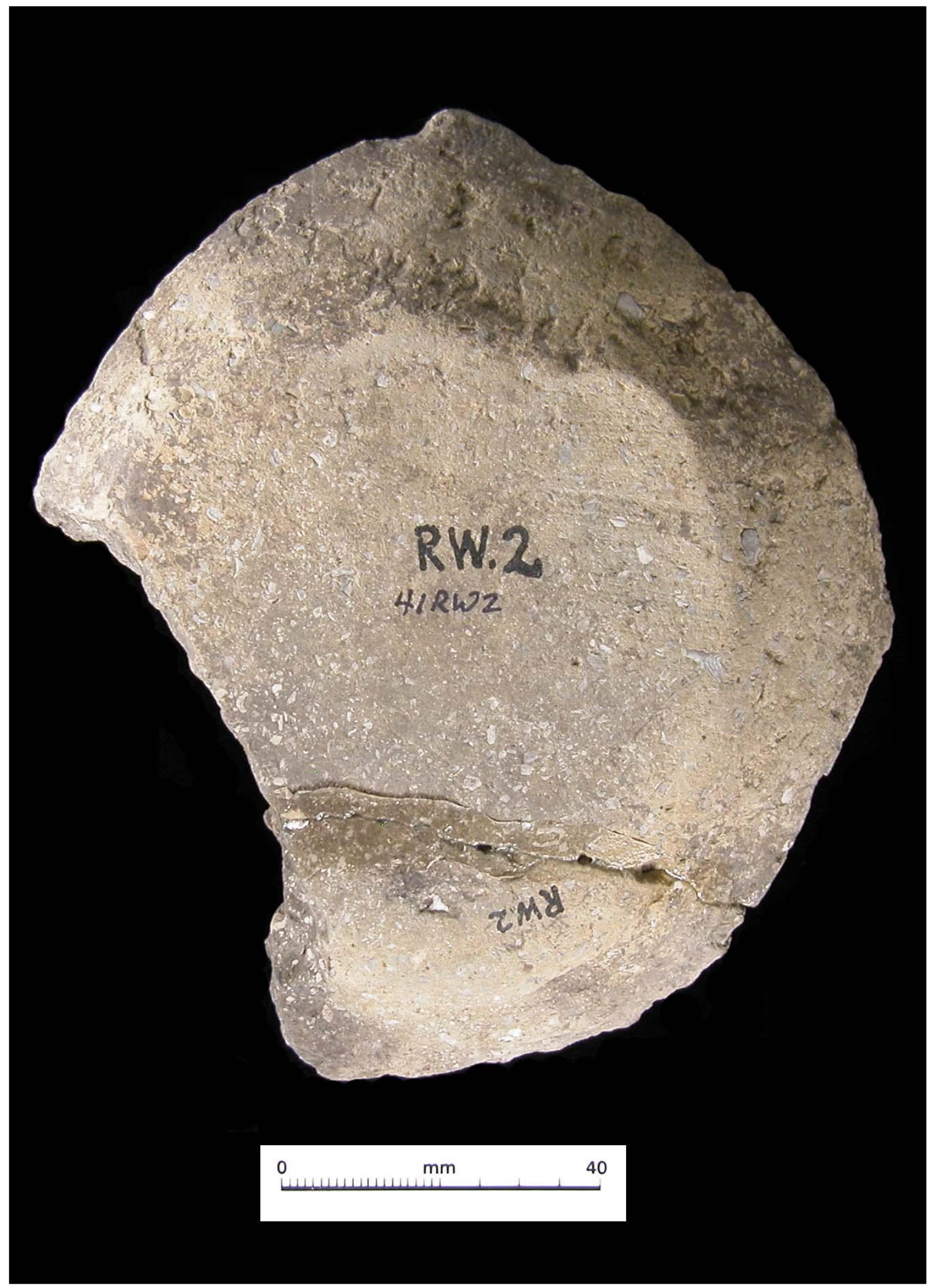

Figure 4. Base of a large, flat-bottomed Nocona Plain vessel from the Upper Rockwall (41RW2) site, Rockwall County, Texas. Note the large pieces of mussel shell temper clearly visible on the surface of the vessel walls. 


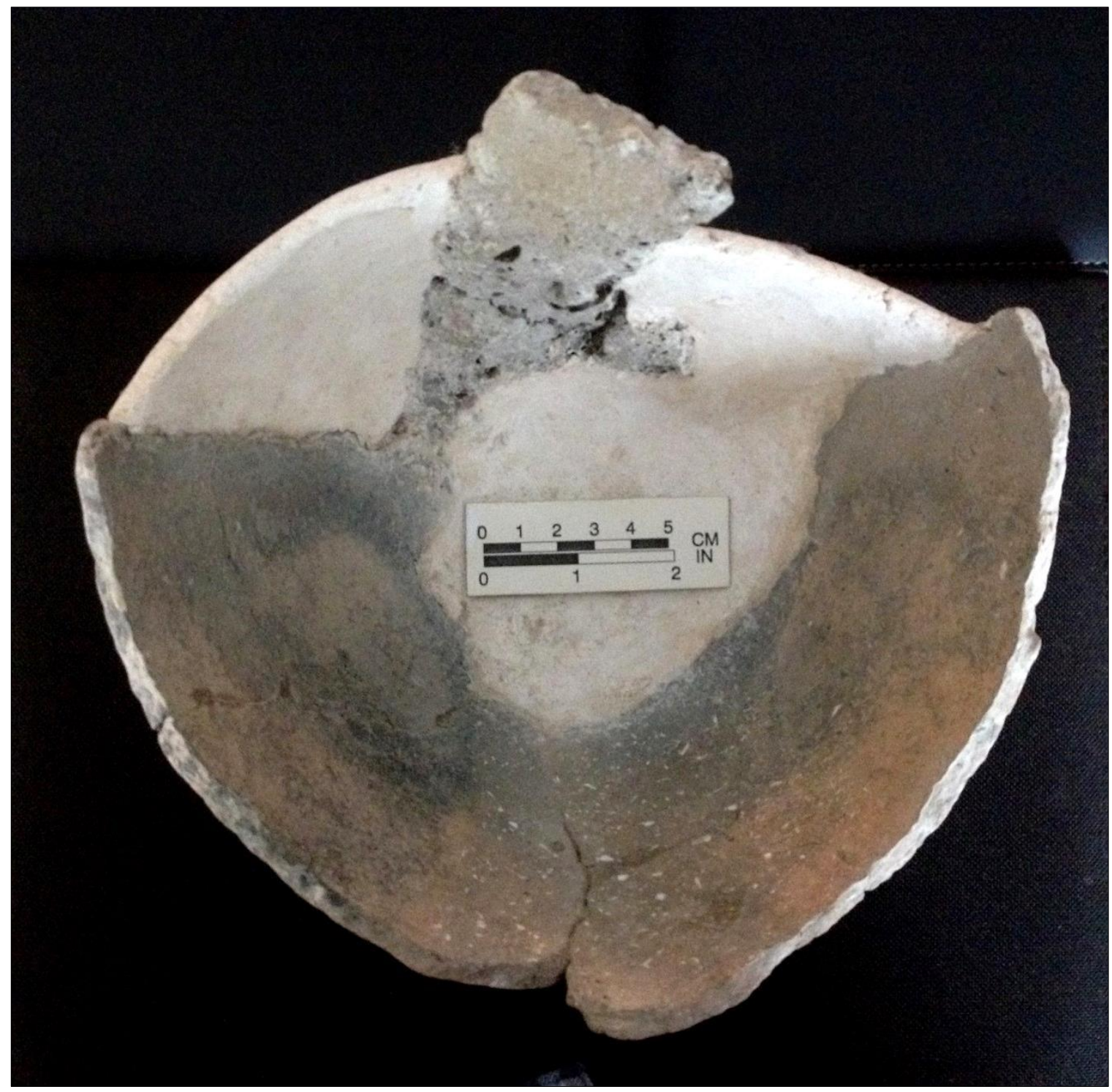

Figure 5. Top view of a large, flat-bottomed Nocona Plain vessel from the Upper Farmersville (41COL34) site, Collin County, Texas. Note the frothy nature of the over-fired portion at the top of the image. The white material is plaster placed to stabilize the reconstruction by the Heard Museum of Natural Science, where the vessel is curated.

The vessel is clearly different from all other shell-tempered ceramics from the East Fork. Overall shape (rounded base as opposed to flat bottom), wall thickness, the presence of strap handles and prominent lip notching all serve to make it unique among shell-tempered ceramics from the East Fork. Moreover, the amount of shell used as temper is considerably less and smaller in size than a typical Nocona Plain vessel. Plain shell-tempered ceramics from Caddo sites along the Red River have generally not been named as most shell-tempered vessels are almost always decorated (Timothy K. Perttula, personal communication, 2014). Plain shell-tempered ceramics from the Lake Texoma area (Haley's Point site, 34MA15) have been described as Woodward Plain, var. Haley's Point, but it has not been described as having strap handles or lip notching (Rohn 1998). The Woodward Plain type as defined is similar to the vessel described herein but again, the presence of handles and lip notching on the Sister Grove Creek specimen is unique (Freeman and Buck 1960). 


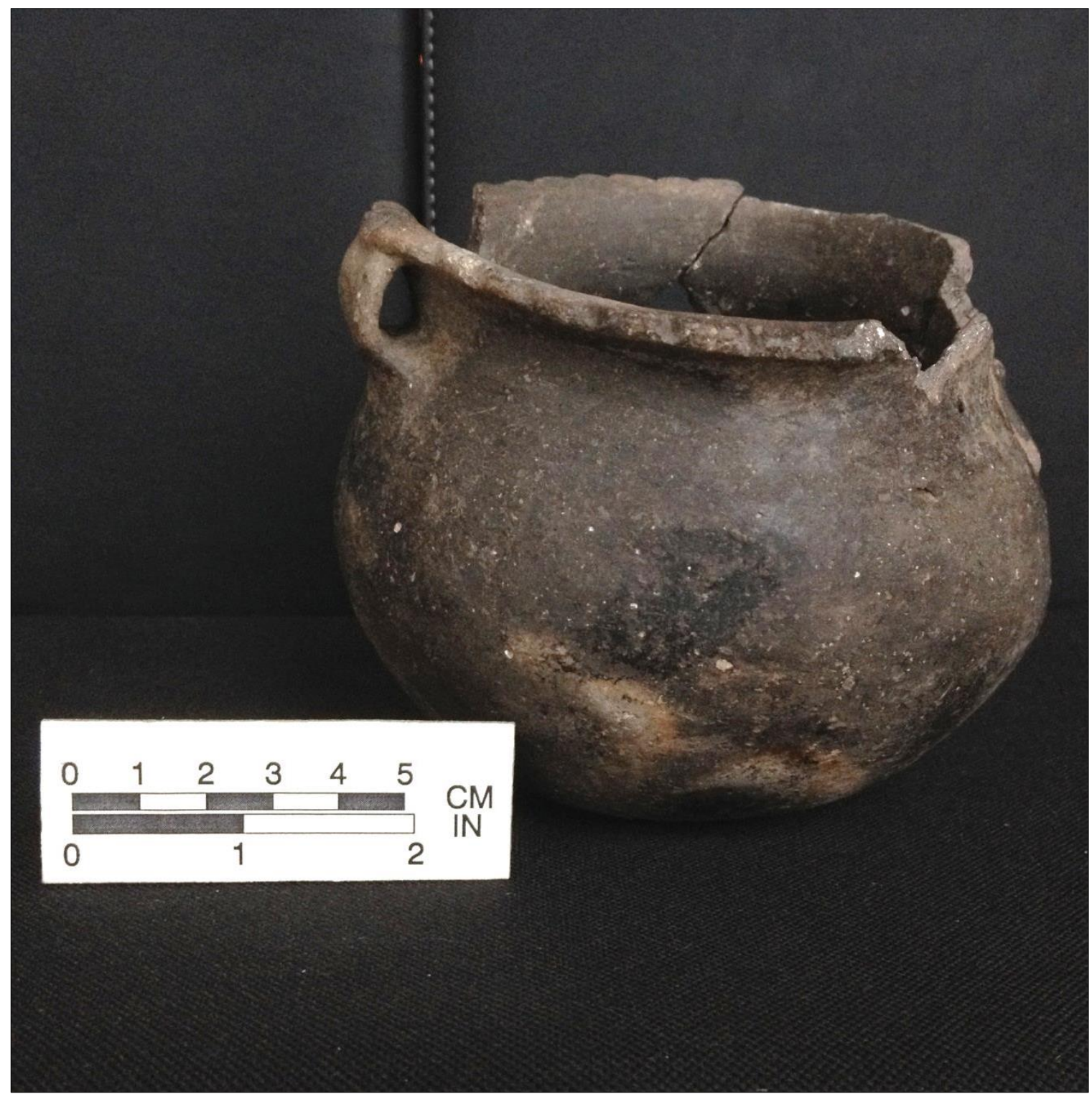

Figure 6. Shell-tempered jar with strap handle from the Sister Grove Creek site (41COL36).

\section{Decorated and Plain Caddo Ceramic Wares}

Approximately 16 percent of the total ceramic assemblage from the East Fork includes sherds from decorated and/or plain Caddo types from various locations in East Texas. Most common are ceramics associated with the Sanders phase. Types present in East Fork sites include Sanders Plain (775 sherds), Sanders Engraved (69 sherds, Figure 7), Monkstown Fingernail Impressed (221 sherds, see bottom row of Figure 3), and Canton Incised (three sherds). There are also 328 sherds of a sandy paste-grog-tempered ceramic that may be a variety of Sanders Plain in that they have a maroon to dark brown slip instead of a red slip. All of these types are characterized by a coarse sandy clay, grog temper, a highly smoothed surface treatment, and frequent slips on vessel interior and exterior surfaces (Sanders Plain and Sanders Engraved in 
particular). Slip colors on sherds from Sanders Plain and Sanders Engraved vessels varies from red to yellowish-orange to maroon, dark brown, or black depending upon whether the vessel was fired in an oxidizing or reducing environments. Vessel shapes are typically large, wide, bowls, jars, and water bottles. Of note, one of the few complete ceramic vessels recovered from the East Fork was a Sanders Engraved water bottle found in a double burial at the Upper Farmersville site (Harris 1948; Harris and Suhm 1963). Sanders phase ceramics originate around the site of the same name in Lamar County and along the Red River, as well as in sites in the upper Sabine River basin.

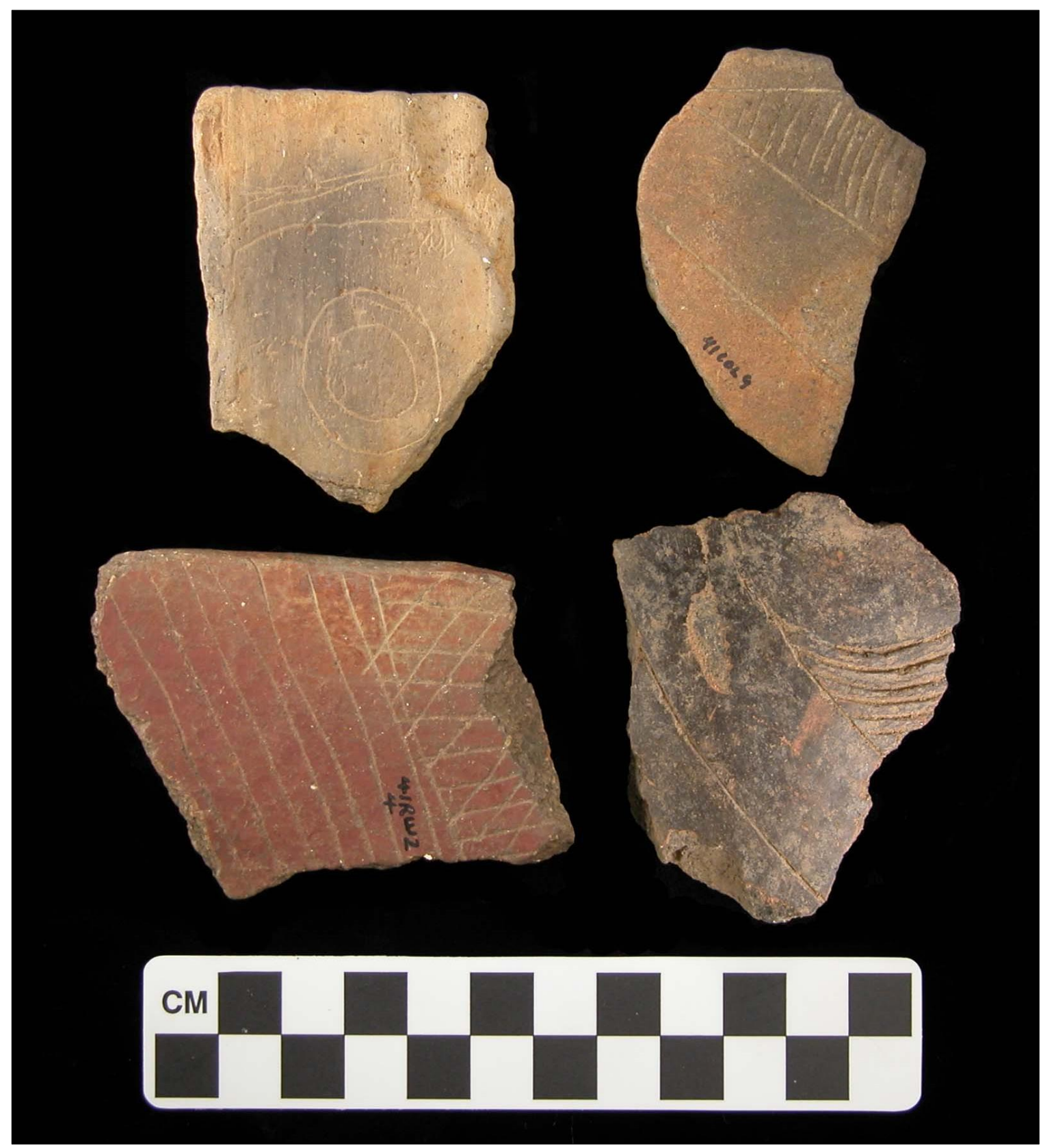

Figure 7. Caddo engraved ceramics from East Fork sites: Top Row L-to-R: Poynor Engraved - Mantooth site (41COL167); Holly Fine Engraved - Branch site (41COL9). Bottom Row L-to-R: Sanders Engraved - Upper Rockwall site (41RW2); Sanders Engraved - Upper Farmersville site (41COL34). 
The age of Sanders phase ceramics is generally thought to be between ca. A.D. 1100-1300, at the end of the Early Caddo period (ca. A.D. 1000-1200) and the early part of the Middle Caddo period (ca. A.D. 12001400) (Perttula 2002), but the phase is not well-dated. This temporal interval corresponds well with radiocarbon dates from Late Prehistoric sites on the East Fork, which largely cluster between ca. A.D. 9801150 and ca. A.D. 1250-1400 (Lynott 1978; Crook and Hughston n.d., in press). Bruseth et al. (1995) and Schambach (1995) both see the Sanders site (41LR2) as the locus of a major trading center, importing Spiroan material and other items from Oklahoma and exporting Caddo ceramics and bois d'arc wood to the north. As the East Fork sites have produced a number of artifacts, including a slate gorget, boatstones, and both polished and chipped stone that appear to have their origins in eastern Oklahoma and southern Arkansas, it is possible that the East Fork inhabitants participated in this exchange system to some limited extent (Crook and Hughston 2008; Skinner et al. 2014; Crook 2014a).

Other Caddo ceramics recovered from the East Fork include a small amount of Alto and Frankston phase ceramics from East Texas. Alto phase ceramic types present in sites along the East Fork includes Crockett Curvilinear Incised (six sherds), Davis Incised (three sherds), Dunkin Incised (one sherd), Holly Fine Engraved (four sherds), Hickory Fine Engraved (three sherds), Pennington Punctated-Incised (12 sherds), and Weches Fingernail Impressed (one partial vessel and three additional sherds, Figure 8). Each of these occurrences is likely only from a single vessel and thus they are not common in East Fork sites. Vessel types include mainly large bowls and jars.

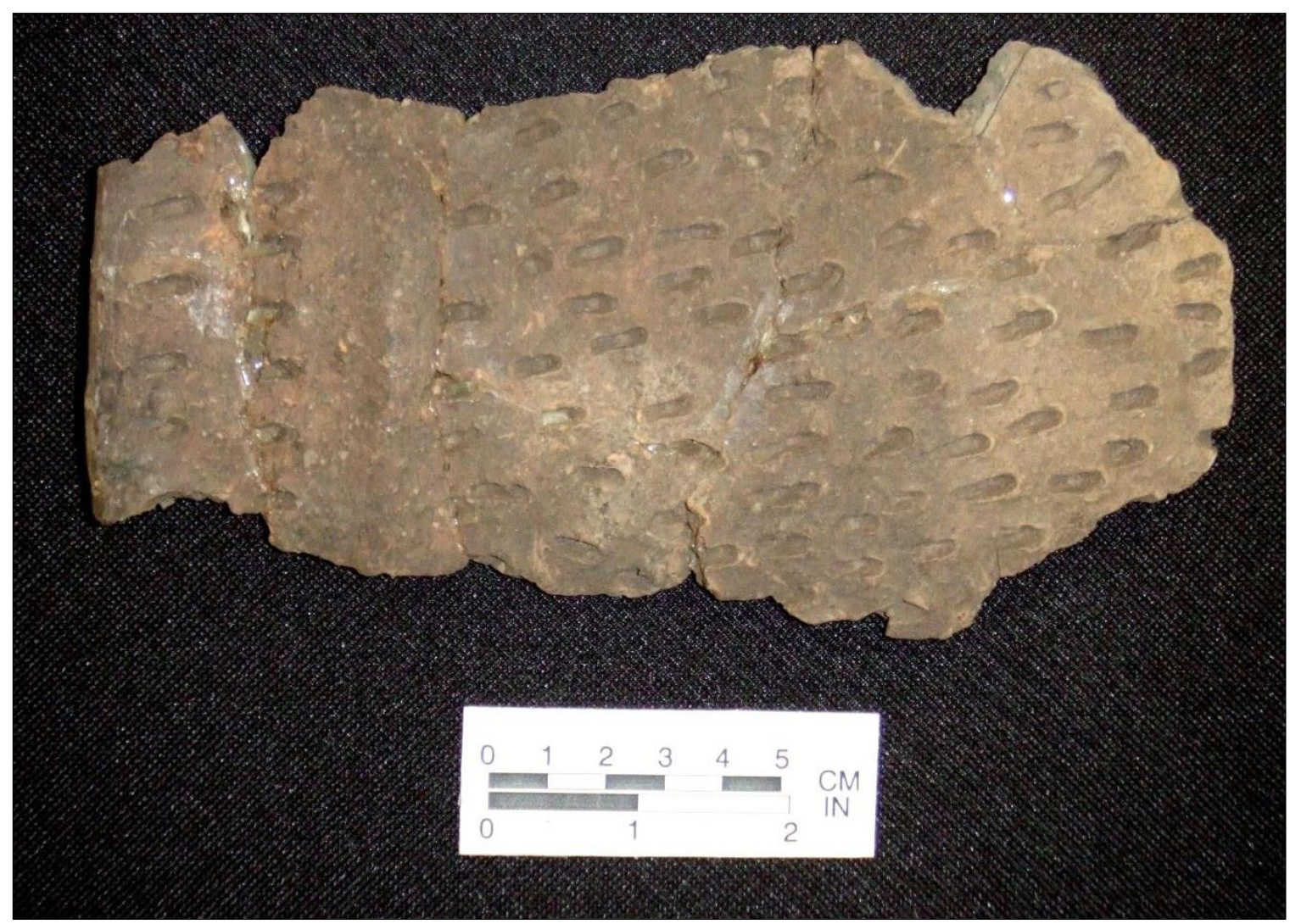

Figure 8. Weches Fingernail Impressed sherd from the Gilkey Hill site (41KF42/41DL406), Kaufman and Dallas counties (from the R. K. Harris Collection currently curated at the Smithsonian Institution). 
Additional Caddo ceramic types found in East Fork sites includes Haley Complicated Incised (one sherd) from the Haley phase in southwestern Arkansas; Harleton Appliqued (two sherds) from the Titus phase; and Hempstead Engraved (one sherd) from the Texarkana phase and farther east in southwestern Arkansas. There are also sherds from Killough Pinched (one complete vessel and 10 other sherds), Maydelle Incised (one vessel reconstructed from 34 sherds and three additional sherds), and Poynor Engraved (one sherd, see Figure 7) vessels, all types from the Frankston phase (both Killough Pinched and Maydelle Incised are also common in Titus phase ceramic assemblages as well as mid-Sabine River basin Middle Caddo sites). Lastly, a single Foster Trailed-Incised vessel (reconstructed from 21 sherds) from the Texarkana and Belcher phases of the Late Caddo period along the Red River was recovered from the Sister Grove Creek site (Crook and Perttula 2008). While these types represent only 74 sherds ( $<0.1$ percent) of the total East Fork ceramic assemblage, several complete vessels have been recovered. These include a small jar of Killough Pinched found in the rim of the pit structure at the Upper Farmersville site (Crook 2014b), the previously mentioned Maydelle Incised jar reconstructed from a find of 34 sherds at the Lower Rockwall site (Crook 2014c), and the Foster TrailedIncised jar found at the Sister Grove Creek site (Crook 2007b; Crook and Perttula 2008).

Ancestral Caddo ceramics from burial features on sites in East Texas indicate that Killough Pinched and Maydelle Incised vessels (Figures 9-10) were made by the Caddo in the Upper Neches River basin, the midand upper-Sabine basin, and in the Big Cypress Creek basin between ca. A.D. 1200-1680 (Perttula 1992; Perttula et al. 2011). Killough Pinched is most common in the Upper Neches River basin in contexts dating after ca. A.D. 1400 (Timothy K. Perttula, personal communication, 2014). The same is true for the Maydelle Incised type.

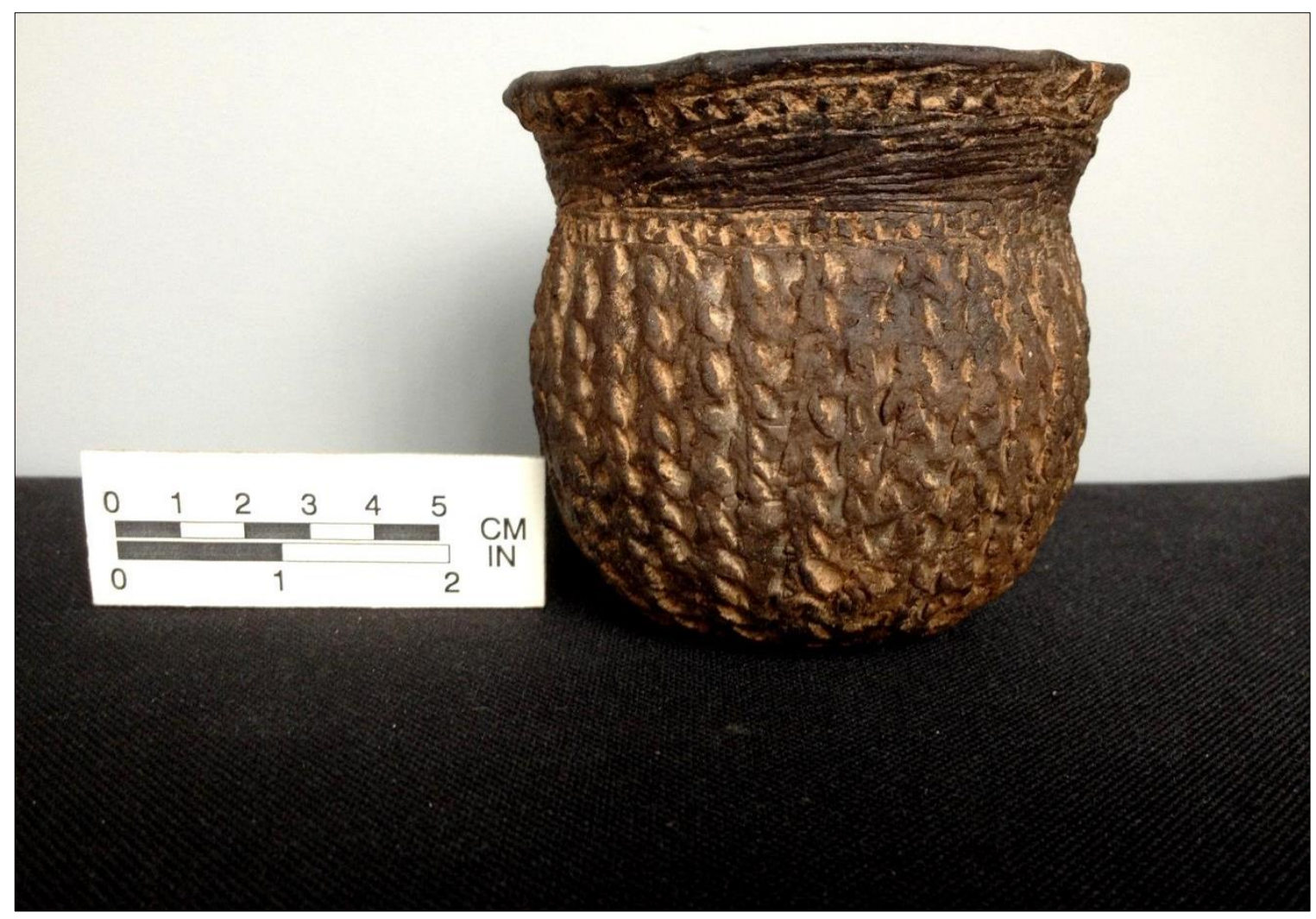

Figure 9. Killough Pinched vessel from the Upper Farmersville site (41COL34). 


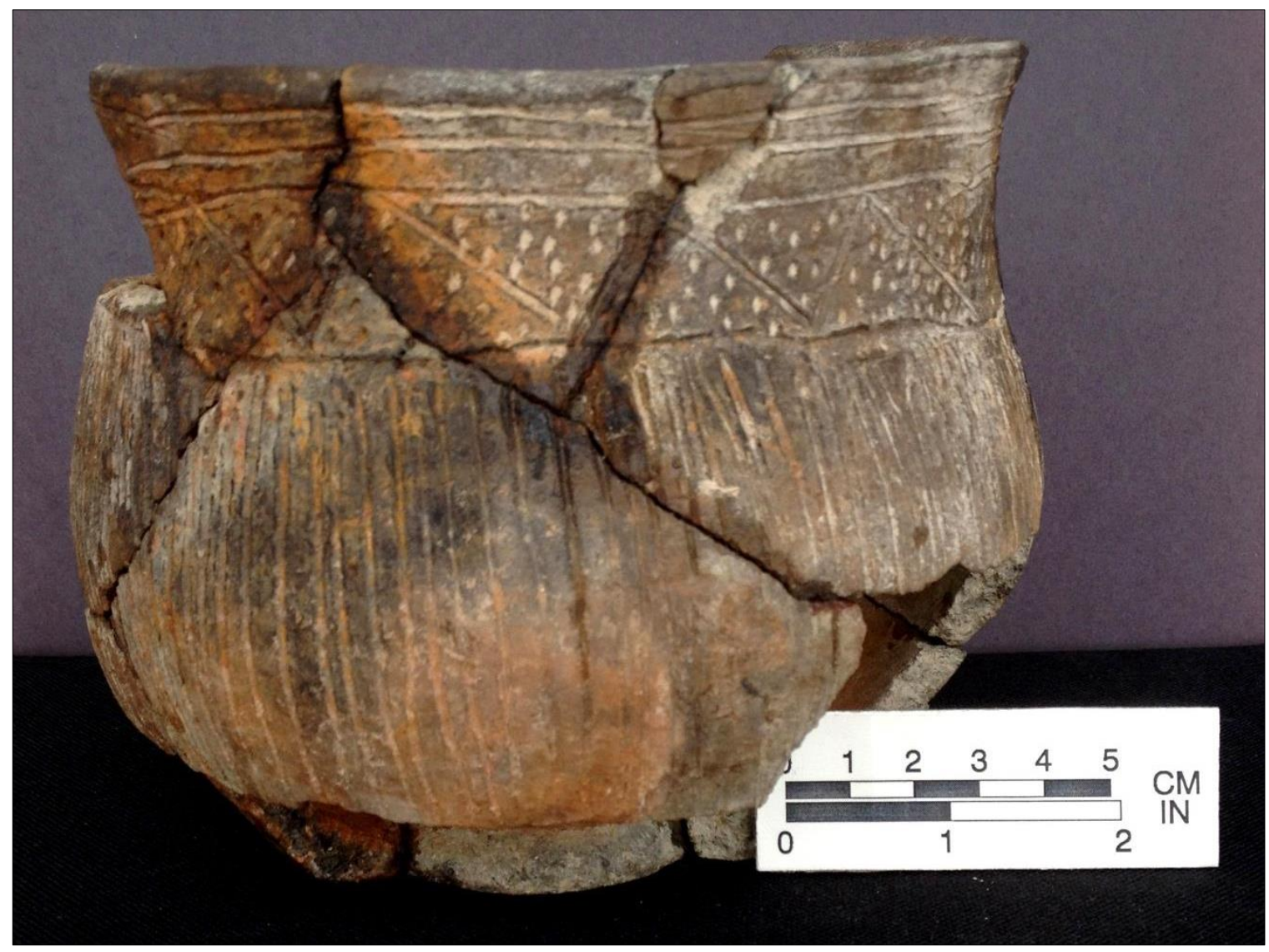

Figure 10. Maydelle Incised vessel reconstructed from 34 sherds found by a local collector in the early 1960 s at the Lower Rockwall site (41RW1).

Foster Trailed Incised (Figure 11) is a relatively common Caddo ceramic type made primarily by the Belcher and Texarkana phase Caddo peoples living in the Great Bend area of the Red River valley in southwestern Arkansas, northwestern Louisiana, and a small part of northeastern Texas (Perttula 2005; Schambach and Miller 1984; Webb 1959). This includes several counties in the southwestern part of Arkansas (Little River, Hempstead, Miller, and Lafayette counties), Bowie County, Texas, and downstream to various sites near Shreveport, Louisiana, in Bossier and Caddo parishes (Webb 1959; Kelley 1997). Ceramic analyses by Schambach and Miller (1984) indicate that different varieties of Foster Trailed-Incised tended to have been made and used by Late Caddo groups between ca. A.D. 1500 and ca. A.D. 1700. This time period corresponds precisely with a calibrated radiocarbon date obtained from the Sister Grove Creek site of A.D. $1590 \pm 70$ (Lynott 1975a, 1978).

\section{Puebloan Ceramics}

A few sherds of Puebloan ceramics have been found at the Upper Farmersville site, the Branch site, a small campsite near the Branch site (Crook 1985), and at the Lower Rockwall site, where an almost complete stirrup-shaped vessel of Arboles Black-on-White was recovered (Lorrain and Hoffrichter 1968). Puebloan ceramic types identified from these four sites include Arboles Black-on-White (one vessel), Black Mesa Blackon-White (two sherds), Chaco Black-on-White (four sherds), Santa Fe Black-on-White (12 sherds), Mimbres 


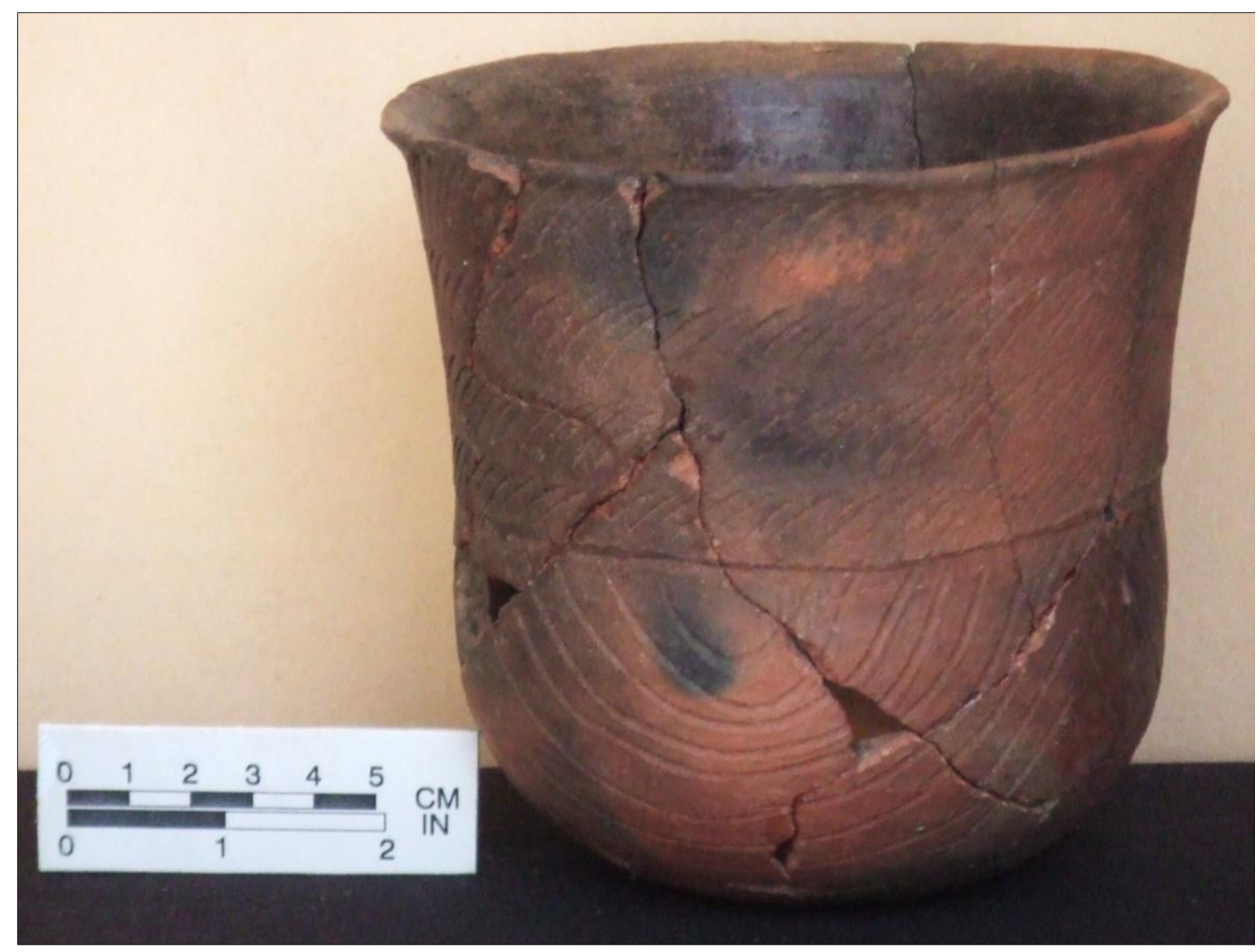

Figure 11. Foster Trailed-Incised jar from the Sister Grove Creek site (41COL36).

Black-on-White (two sherds), Jemez Black-on-White (one sherd), Rio Grande Glaze ware (three sherds), Chupadero Black-on-White (two sherds), and Zuni Glaze (one sherd) (Figure 12 and Table 2). In addition, a shaped sherd of an unidentified, highly-weathered Black-on-White type was found at the Branch site.

At both the Upper Farmersville and Branch sites, other artifacts of Puebloan origin in addition to ceramics have been recovered, including obsidian and chalcedony arrow points, worked flakes, Olivella shell beads, and turquoise (Crook 2013; Crook n.d., in press). X-Ray Fluorescence (XRF) analysis of the obsidian artifacts, specifically bivariate plots of zirconium with rubidium and yttrium with zirconium, indicates a north central New Mexico origin, including El Rechuelos ("Polvadera Peak") and Valles Rhyolite (Crook n.d., in press). XRF analysis of the turquoise is indicative of Los Cerrillos material from the same region.

The age of the Puebloan ceramics ranges from ca. A.D. 900-1100 for Arboles Black-on-White (McIntyre and McGregor 1982) to A.D. 1300-1700 for Rio Grande Glaze ware and Jemez Black-on-White, as well as the period in between. These ages correspond to the Developmental Period (Pueblo II), the Coalition Period (Pueblo III), and the Classic Period (Pueblo IV), and correlate well with the radiocarbon data from the East Fork that cluster around ca. A.D. 980-1150 and 1250-1400+ (Lynott 1975a; Crook and Hughston, in press). Most of these ceramic types originate in north central to northwestern New Mexico, matching well with the obsidian XRF data. 


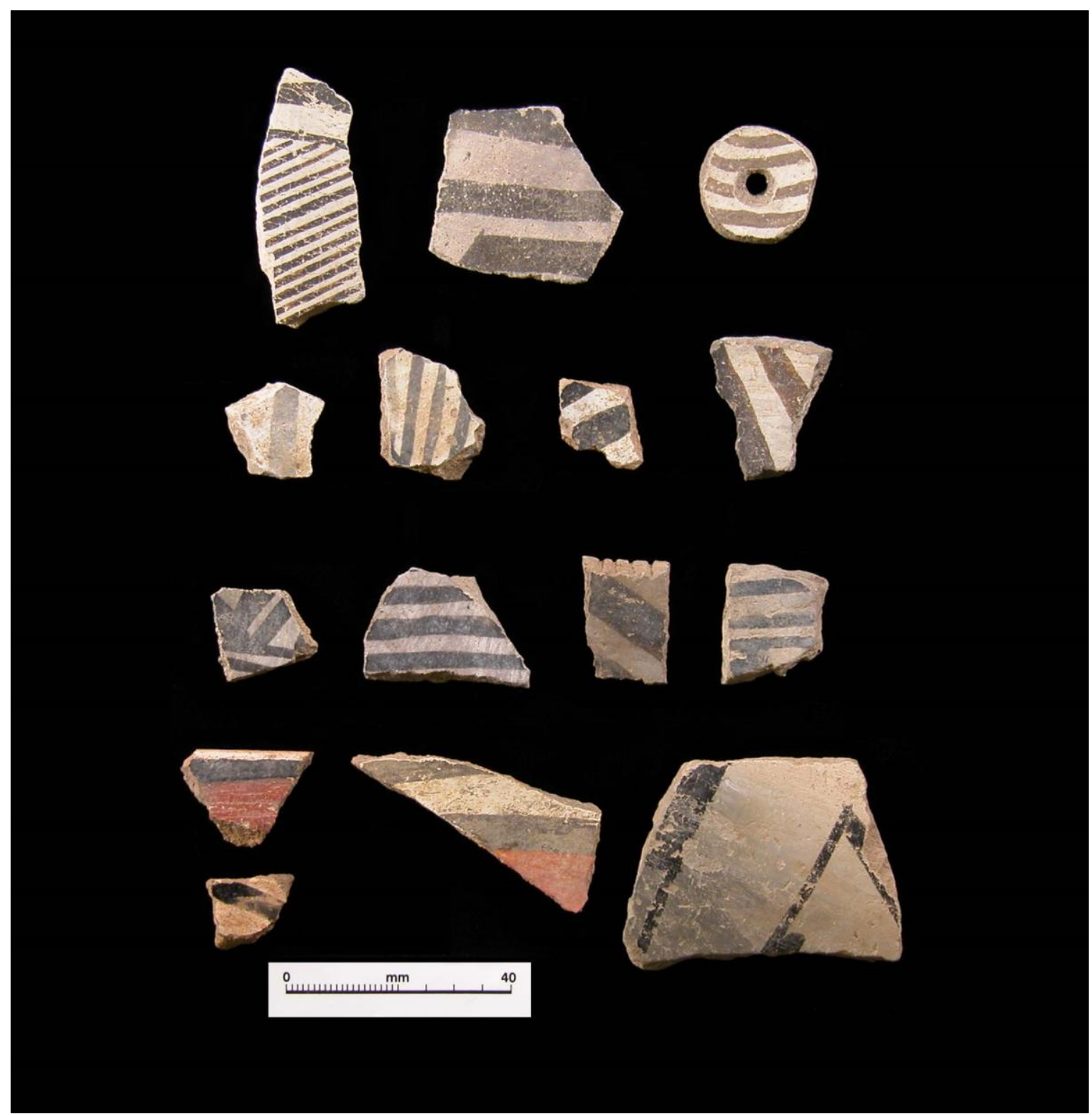

Figure 12. Puebloan ceramics from Late Prehistoric sites along the East Fork. Top Row L-to-R: Chupadero Black-onWhite (2), Mimbres (Classic III) Black-on-White - Branch (41COL9); Second Row L-to-R: Chaco Black-on-White Upper Farmersville (41COL34); Third Row L-to-R: Santa Fe Black-on-White - Upper Farmersville (41COL34); Bottom Row L-to-R: Rio Grande Glaze - Upper Farmersville (41COL34). 


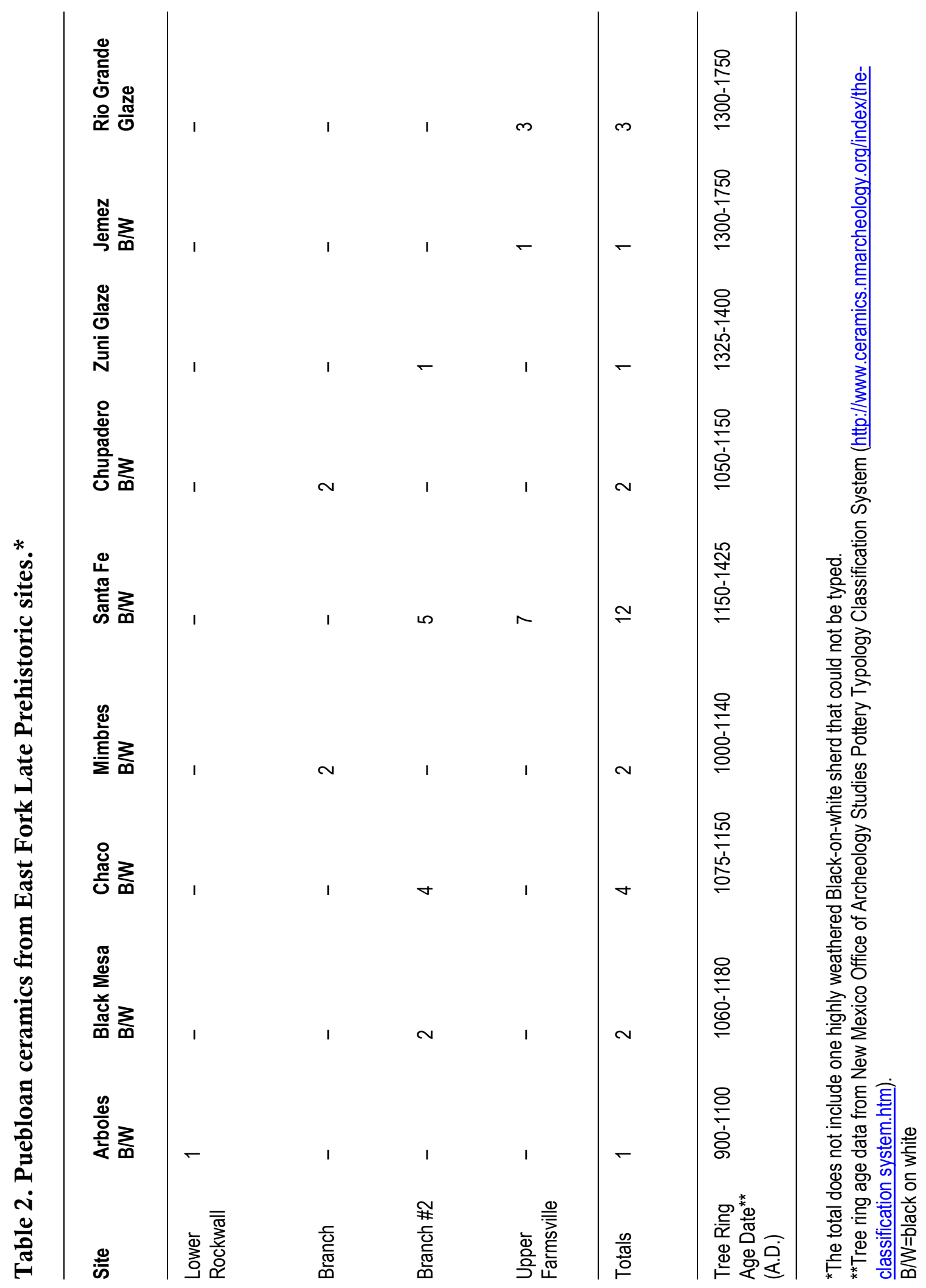




\section{CONCLUSIONS}

Ceramics are a consistent item in almost all Late Prehistoric sites along the East Fork of the Trinity. However, the number of recovered sherds $(\mathrm{n}=10,217)$ is not a particularly high amount given the number of sites and the length of time ceramics were probably present in the district (ca. A.D. 800-1600). As a result, while present, ceramics are a relatively minor component of site artifact assemblages relative to lithic artifacts.

Beginning sometime before A.D. 900, Williams Plain flat-bottomed jars were introduced into the East Fork. While no complete vessels of Williams Plain have been recovered from the East Fork, basal and rim sherds indicate that most if not all vessels were thick, medium-sized, flat-bottomed bowls and jars. While there is no direct evidence for the local manufacture of Williams Plain along the East Fork, however, their sheer number $(n=3,642)$ indicates that most, if not all, of the sherds are from vessels produced locally. Williams Plain continued to be the predominant ceramic type in the region until ca. A.D. 1200-1300.

Based on stratigraphic evidence from Upper Farmersville (Crook and Hughston 2009, n.d., in press), Branch (Crook 2007), and Upper Rockwall (Ross 1966; Valastro et al. 1967), distinctive Caddo ceramics of the Sanders and Alto phases appear in small numbers in the largest East Fork sites between ca. A.D. 11001300. Evidence of this includes the presence of sherds of the Sanders Plain, Sanders Engraved, Monkstown Fingernail Impressed, Canton Incised, Crockett Curvilinear Incised, Pennington Punctated-Incised, Weches Fingernail Impressed, and Holly Fine Engraved types. Given the relatively limited nature of these ceramics (less than 10 percent of the total ceramic assemblage for the East Fork), their presence is likely the result of exchange rather than local manufacture. Additional exotic items appear on East Fork sites in the same time frame, including an engraved slate gorget from the Upper Rockwall site (Skinner et al. 2014), boatstones from igneous rock from Upper Farmersville (Crook and Hughston 2009), a cache of unique Cahokia-like arrow points made from Ouachita cherts from the Upper Farmersville site (Crook 2009), and polished conch shell and conch beads from a number of sites (Crook and Hughston 2008).

The limited nature of this exchange is evidenced by the high value placed on exchange items. For example, the neck on the Sanders Engraved water bottle found at the Upper Farmersville site had been broken near the lip but had been meticulously sanded to maintain its usefulness prior to the owner's death (Harris 1948). Its final placement in a burial in between a man and a woman facing each other also signifies its value as a high status item (Crook and Hughston 2009). Similarly, a well-made Sanders Engraved bowl was placed with a high status burial in the rim-and-pit structure at the Upper Rockwall site that dated to A.D. $1300 \pm 120$ (Ross 1966; Valastro et al. 1967).

Sometime around this time (ca. A.D. 1200-1300), shell-tempered plain ceramics were introduced into and began to made locally on the East Fork. This is evidenced by the proliferation of Nocona Plain pottery, which then subsequently became the single most common ceramic type on East Fork sites (48 percent of the total ceramic assemblage). Coincident with this development was the increase in bison herds throughout the southern Plains and into north central Texas (Lynott 1979; Lohse et al. 2014). Undoubtedly hunting forays to the west brought the East Fork inhabitants into contact with Henrietta phase peoples of the southern Great Plains, and the exchange of technology led to the manufacture and use of shell-tempered wares. 
Concurrent with this contact with Henrietta phase peoples was a further link to the west with the Puebloan peoples of northern and northwestern New Mexico. While not abundant, Pueblo ceramics, obsidian artifacts, turquoise, as well as red coral and Olivella sp. shell from Baja California have all been found in East Fork sites (Crook 1985, 2013). Moreover, based on the ceramic types present, this contact (either directly or via an intermediary) occurred several times from at least A.D. 1000 to as late as A.D. 1400-1500 (Crook 2013).

A very limited amount of interaction was also established with the Caddo peoples living to the east/southeast in the upper parts of the Neches, Angelina, and Sabine River basins. On the East Fork, this contact is represented by sherds from Frankston phase ceramics including Killough Pinched, Maydelle Incised, and Poynor Engraved (Perttula 2002; Perttula et al. 2007; Perttula et al. 2011). Ceramic analyses indicate that many of these pottery types were primarily made and used by the Caddo after A.D. 1400, especially Poynor Engraved vessels (Timothy K. Perttula, personal communication, 2014). Given the very limited presence of these ceramic types (typically less than 10 sherds of each type for the entire district), their occurrence is mostly likely the result of exchange and not the product of local manufacture. The local value of such items is supported by the burial of single Killough Pinched and a Maydelle Incised vessels in the rims of the large, central rim-and-pit structures at the Upper Farmersville and Lower Rockwall sites (Crook 2014b, 2014c).

The acquisition of Caddo (and Puebloan) materials begs the question: what did the inhabitants of the East Fork have to exchange for these ceramics and other goods? Three natural resources were abundant in the region: (1) whitetail deer, (2) quartzite, and (3) potentially bois d'arc wood. Whitetail deer and quartzite were items common to all of East Texas and thus were probably not exchangeable goods. However, bois d'arc, along with the English yew tree, is the finest wood for the construction of bows in the world. This is due to its incredible work to maximum load strength which is as much as two to three times that of most local woods (Bush 2014). As such, bois d'arc was in continual demand by those people who used the bow and arrow and lived outside its natural range. This would include the Henrietta phase people of the southern Great Plains, the Puebloan peoples of New Mexico, the Spiroan trade centers of eastern Oklahoma and their extensive trade partners, and even some of the more southern Caddo groups.

In is unknown if bois d'arc trees were present along the East Fork during the Late Prehistoric. Schambach (1995) has proposed that bois d'arc in Texas was originally limited to a small area along Bois d'Arc Creek in Fannin County. Jurney $(1988,1994)$ and Weniger (1996) studied Texas General Land Office records prior to 1860 and concluded that the original distribution of bois d'arc was limited to a 12 county area of Northern Texas, including the area occupied by East Fork Late Prehistoric peoples (Collin, Rockwall, northwestern Kaufman, and extreme northeastern Dallas counties) (Figure 13). In fact, the distribution of East Fork Late Prehistoric sites (see Figure 1) is almost coincident with Jurney's known distribution of bois d'arc (Jurney 1988, 1994), a remarkable coincidence if bois d'arc was not present at the time. 


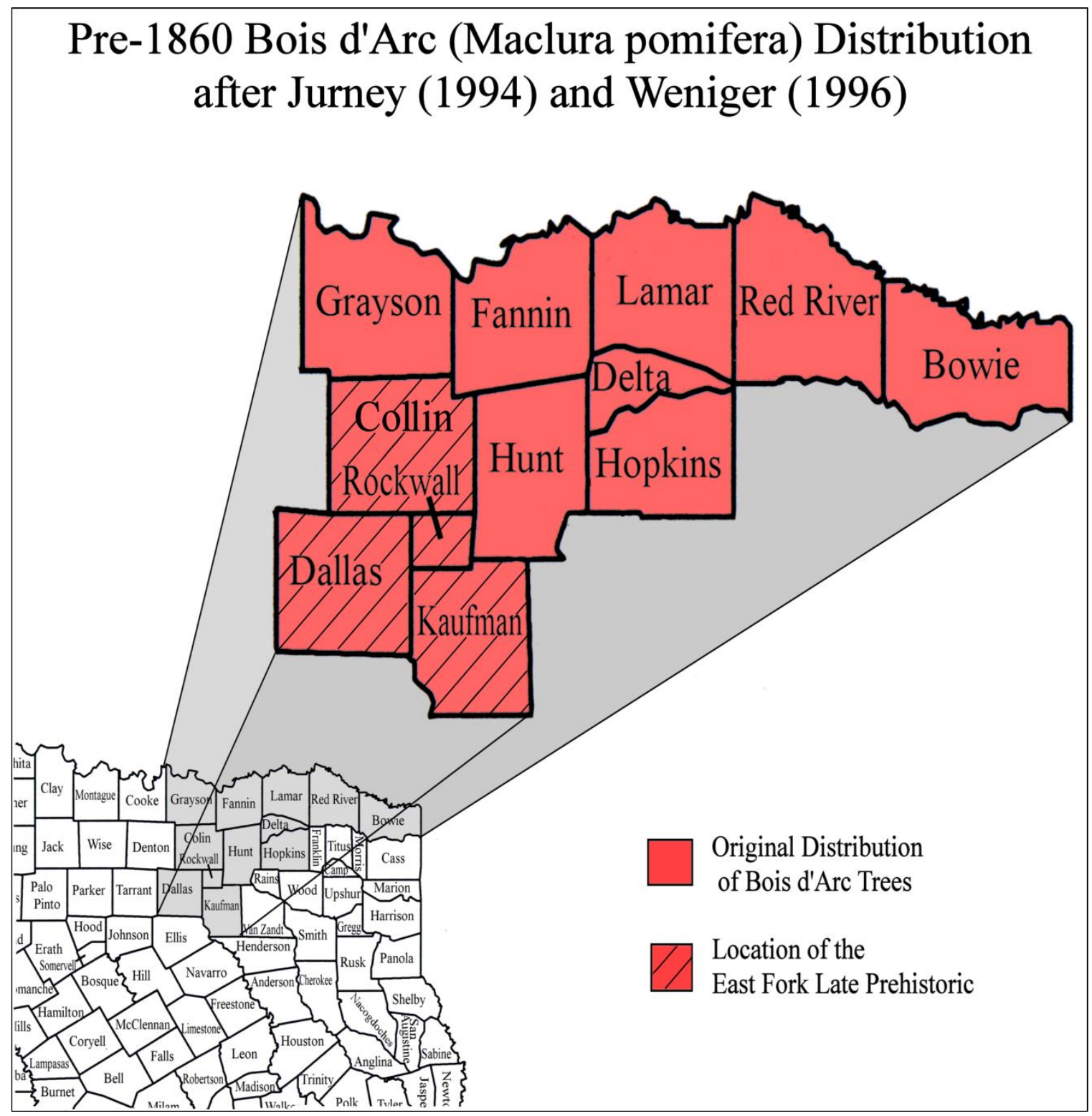

Figure 13. Pre-1860 distribution of Bois d'Arc trees in Northern Texas, after Jurney (1994) and Weniger (1996). Counties containing East Fork Late Prehistoric period sites are cross-hatched.

Our research has identified a distinctive sub-triangular shaped scraper (the "East Fork Biface") that has been shown experimentally to be a specialized woodworking tool (Crook and Hughston 2007). Experimental evidence on green bois d'arc has produced the same type of edge crushing and wear striations seen on recovered archeological specimens. It is postulated, therefore, that if bois d'arc was indeed present along the East Fork in Late Prehistoric times, the aboriginal peoples living on the East Fork then likely produced staves of bois d'arc both for internal use but also for export in exchange for ceramics and other items of value not indigenous to the region (Crook 2014a). 


\section{ACKNOWLEDGMENTS}

We are indebted to the many previous researchers in the area who openly shared their knowledge about the Late Prehistoric occupations of the region. Foremost among these were the late R. K. "King" Harris, R. L. "Bob" Stephenson, Rex Housewright, Lester Wilson, and Bobby Vance of the Dallas Archeological Society. We also thank Mr. John McCraw of McKinney, Texas, and the late Mr. Raymond Gouch of Farmersville, who opened their extensive collections to us for study. We are also grateful to Dr. James Krakker of the Smithsonian Institution (Museum Support Center) for allowing us access to the R. K. Harris collection, and to Ms. Laura Nightengale who offered us unlimited access to the East Fork collections present at the Texas Archeological Research Laboratory in Austin. Of particular note are the many wonderful photographs of East Fork artifacts that Laura took, several of which appear in this article, to aid us in our research. Identification of the Puebloan types was greatly assisted by the late Dr. Joel Shiner and Dr. Ron Wetherington, both of Southern Methodist University. In addition, we used the type collections at the Texas Archeological Research Laboratory at the University of Texas at Austin and the New Mexico Office of Archeological Studies Pottery Typology Classification System (http//www.ceramics.nmarcheology.org/ index/the-classification-system.htm). Lastly, we would like to specifically thank the Heard Natural Science Museum (McKinney, Texas) and the Collin County Historical Society who sponsored the original portions of this research.

\section{REFERENCES CITED}

Bell, Robert E. and Robert L. Brooks

2001 Plains Village Tradition: Southern. In Handbook of North American Indians, Plains, Volume 13, edited by Raymond J. DeMallie, pp. 207-221. Smithsonian Institution, Washington, D.C.

Brack, Michael L.

1999 Shell Tempered Ceramics of the Late Prehistoric Southern Plains: Toward a Cultural Understanding of Nocona Plain. Master's Thesis, Wichita State University, Wichita, Kansas.

Brown, James A.

1996 The Spiro Ceremonial Center. The Archaeology of Arkansas Valley Caddoan Culture in Eastern Oklahoma. 2 Vols. Memoir No. 29. Museum of Anthropology, University of Michigan, Ann Arbor.

Bruseth, James E. and William A. Martin

1987 The Wylie Focus: Cultural Reality or Archeological Myth? In The Bird Island and Adams Ranch Sites: Methodological And Theoretical Contributions to North Central Texas Archeology, edited by James E. Bruseth and William A. Martin, pp. 267-284. Richland Technical Series, Vol. 2, Archaeology Research Program, Southern Methodist University, Dallas.

Bruseth, James E., Diane E. Wilson, and Timothy K. Perttula

1995 The Sanders Site: A Spiroan Entrepot in Texas? Plains Anthropologist 40(153):223-236. 
Bush, Leslie L.

2014 Evidence for a Long-Distance Trade in Bois d'Arc Bows in $16^{\text {th }}$ Century Texas (Maclura pomifera, Moraceae). Journal of Texas Archeology and History 1:51-69.

Cliff, Maynard

1998 Not With a Bang, But a Whimper: The End of the Archaic in Northeast Texas. Journal of Northeast Texas Archaeology 11:100-107.

Coffee, Donald R., Ralph H. Hill and Dennis D. Ressel

1980 Soil Survey of Dallas County, Texas. U.S. Department of Agriculture, Soil Conservation Service in cooperation with Texas Agricultural Experiment Station, Washington, D.C.

Crook, Wilson W., III

1985 The Branch \#2 Site: A Northeast Texas Puebloan Intrusive Contact. Texas Archeology (Newsletter of the Texas Archeological Society) 29(3):9-11.

1987380 Bridge Site (41COL66): A Small Wylie Focus Village in Collin County, Texas. Texas Archeology (Newsletter of the Texas Archeological Society) 31(4):7-8.

1989 The Enloe Site (41COL65): A Diagnostic Wylie Occupation in Collin County, Texas. Texas Archeology (Newsletter of the Texas Archeological Society) 33(1): 10-11.

2007a The Branch Site (41COL9): A Large Diagnostic Late Prehistoric Occupation in Collin County, Texas. The Record 55(2):30-44. Dallas Archeological Society, Dallas.

2007b An Unusual Ceramic Vessel From The Sister Grove Creek Site, Collin County, Texas. The Record 55(2):69-73. Dallas Archeological Society, Dallas.

2009 A Unusual Late Prehistoric Point Concentration from the Upper FarmersvilleSite (41COL34), Collin County, Texas. The Journal 132:21-36. Houston Archeological Society, Houston.

2013 Puebloan Intrusive Artifacts in Archeological Sites Along the East Fork. Archeological Journal of the Texas Prairie Savannah 3(1):36-43.

2014a New Evidence for Ceramic Trade Between the Late Prehistoric Occupants of the East Fork and the Caddo Peoples. Paper presented at the $56^{\text {th }}$ Caddo Conference, Tyler, Texas, March 27-29.

2014b A Small Killough Pinched Vessel from the Upper Farmersville Site (41COL34), Collin County, Texas. Archeological Journal of the Texas Prairie-Savannah 4(1):44-50.

2014c A Maydelle Incised Jar from the Lower Rockwall Site (41RW1), Rockwall County, Texas. Archeological Journal of the Texas Prairie-Savannah 4(1):50-56. 
n.d. An Occurrence of Turquoise and Obsidian at the Branch Site (41COL9), Collin County, Texas. Archeological Journal of the Texas Prairie-Savannah, in press.

Crook, Wilson W. III and Mark D. Hughston

1986 A Wylie Focus Bowl From Collin County, Texas. Texas Archeology (Newsletter of the Texas Archeological Society) 30(3):12-14.

2007 The East Fork Biface: A New Distinctive Artifact From North Central Texas. The Record 55(2):48-64. Dallas Archeological Society.

2008 The Late Prehistoric of the East Fork of the Trinity River: A Redefinition of the Wylie Focus. Paper presented at the Texas Archeological Society $79^{\text {th }}$ Annual Meeting, October 24-25, Lubbock.

2009 The Upper Farmersville Site (41COL34): A Large Diagnostic Late Prehistoric Occupation in Collin County, Texas. The Record 56(1):25-46. Dallas Archeological Society, Dallas.

n.d. Two New Radiocarbon Dates from the Upper Farmersville Site (41COL34). Collin County, Texas. Archeological Journal of the Texas Prairie-Savannah, in press.

Crook, Wilson W. III and Timothy K. Perttula

2008 A Foster Trailed-Incised Vessel from the Sister Grove Creek Site (41COL36), Collin County, Texas. Caddo Archeology Journal 18:22-25.

Dawson, Gerald L. and Timothy L. Sullivan

1969 Excavations at Lake Lavon: 1969. Report to the National Park Service by the Archeology Research Program, Department of Anthropology, Southern Methodist University, Dallas.

Freeman, Joan E. and A. D. Buck

1960 Woodward Plain and Neosho Punctate, Two Shell Tempered Pottery Types of Northeastern Oklahoma. Bulletin of the Oklahoma Anthropological Society 8:3-16.

Hanson, Arthur and Frankie F. Wheeler

1969 Soil Survey of Collin County, Texas. USDA, Soil Conservation Service in cooperation with the Texas Agricultural Experiment Station, Washington, D.C.

Harris, R. K.

1948 A Pottery Site Near Farmersville, Texas. The Record 6(10):38-45. Dallas Archeological Society.

Harris, R. K. and Dee Ann Suhm

1963 An Appraisal of the Archeological Resources of Forney Reservoir, Collin, Dallas, Kaufman and Rockwall Counties, Texas. Report Submitted to the National Park Service by the Archeological Salvage Project, University of Texas at Austin. 
Jurney, David H.

1988 Early Vegetation recorded in the GLO Surveys. The Record 42(3):170-176. Dallas Archeological Society, Dallas.

1994 The Original Distribution of Bois d'Arc Part I: Texas. Caddoan Archeology Newsletter 5(2):6-13.

Kelley, David B. (editor)

1997 Two Caddoan Farmsteads in the Red River Valley: The Archeology of the McLelland and Joe Clark Sites. Research Series No. 51. Arkansas Archeological Survey, Fayetteville.

Krause, Richard A.

2007 A Potter's Tale. In Plains Village Archaeology: Bison-hunting Farmers in the Central and Northern Plains, edited by Stanley A. Ahler and Marvin Kay, pp. 32-40. University of Utah Press, Salt Lake City.

Lohse, Jon C., Brendan J. Culleton, Stephen L. Black, and Douglas J. Kennett

2014 A Precise Chronology of Middle to Late Holocene Bison Exploitation in the Far Southern Great Plains. Journal of Texas Archeology and History 1:94-126.

Lorrain, Dessamae and Norma Hoffrichter

1968 The Lower Rockwall Site, Rockwall County, Texas. Report to the National Park Service by the Salvage Project of Southern Methodist University, Dallas.

Lynott, Mark J.

1975a Archeological Investigations at Lake Lavon, 1974. Contributions in Anthropology 16. Department of Anthropology, Southern Methodist University, Dallas.

1975b Wylie Focus Pits in Light of Recent Investigations. The Record 31(2):1-4. Dallas Archeological Society.

1978 Radiocarbon Dating of the Wylie Focus in Northcentral Texas. Plains Anthropologist 22(77): 233-237.

1979 Prehistoric Bison Populations in Northcentral Texas. Bulletin of the Texas Archeological Society 50:89-101.

Marmaduke, William S.

1975 The Wylie Focus: A Reassessment by the Analysis of Three Typical Sites. Unpublished Master's Thesis, University of Texas at Austin.

McIntyre, Alan J. and Daniel E. McGregor

1982 A Petrographic Analysis of Southwestern Trade Vessel Recovered in Rockwall County, Texas. In Season One (1982) Migration of Prehistoric Archeology in the Richland/Chambers Reservoir, Navarro and Freestone Counties, Texas: Interim Report, edited by Alan J. McIntyre, pp. 513-520. Archaeology Research Program, Southern Methodist University, Dallas. 
Perttula, Timothy K.

1992 "The Caddo Nation": Archaeological \& Ethnohistoric Perspectives. University of Texas Press, Austin.

2002 Archaeological Evidence for the Long-Distance Exchange of Caddo Indian Ceramics in the Southern Plains, Midwest, and Southeastern United States. In Geochemical Evidence for LongDistance Exchange, edited by Michael D. Glascock, pp. 89-107. Bergin and Garvey, Westport, Connecticut.

2005 1938-1939 WPA Excavations at the Hatchel Site (41BW3) on the Red River in Bowie County, Texas. Southeastern Archaeology 24(2):180-198.

Perttula, Timothy K., Bo Nelson, Mark Walters, and LeeAnna Schniebs

2007 Archeological Investigations of the Lang Pasture (41AN38) Midden Deposits on Private Property West of the SH 155 Right-of-way, Anderson County, Texas. Caddo Archeology Journal 16:27-36.

Perttula, Timothy K., David B. Kelley, and Robert A. Ricklis (assemblers and editors)

2011 Archeological Investigations at the Lang Pasture Site (41AN38) in the Upper Neches River Basin of East Texas. Archeological Studies Program Report No. 129, Environmental Affairs Division, Texas Department of Transportation, and Technical Report No. 174202, TRC Environmental Corporation, Austin.

Prikryl, Daniel J.

1990 Lower Elm Fork Prehistory. Report 37. Office of the State Archeologist, Texas Historical Commission, Austin.

Pringle, Fred

1977 Soil Survey of Kaufman and Rockwall Counties, Texas. USDA Soil Conservation Service in cooperation with the Texas Agricultural Experiment Station, Washington, D.C.

Rohn, Arthur H.

1998 Haley's Point (34MA15) on the Red River Marshall County, Oklahoma (Area F). Publications in Anthropology No. 4. Wichita State University, Wichita, Kansas.

Ross, Richard E.

1966 The Upper Rockwall and Glen Hill Sites, Forney Reservoir, Texas. Papers of the Texas Archeological Salvage Project 9. University of Texas, Austin.

Schambach, Frank F.

1995 A Probable Spiroan Entrepot in the Red River Valley in Northeast Texas. Caddoan Archeology Newsletter 6(1):9-25.

1998 Pre-Caddoan Cultures in the Trans-Mississippi South: A Beginning Sequence. Research Series 53. Arkansas Archeological Survey, Fayetteville. 
2001 Fourche Maline and its Neighbors: Observations on an Important Woodland Period Culture of the Trans-Mississippi South. The Arkansas Archeologist 40:21-50.

2002 The Fourche Maline: A Woodland Period Culture of the Trans-Mississippi South. In The Woodland Southeast, edited by David G. Anderson and Robert C. Mainfort Jr., pp. 91-112. University of Alabama Press, Tuscaloosa.

Schambach, Frank F. and John E. Miller III

1984 A Description and Analysis of the Ceramics. In Cedar Grove: An Interdisciplinary Investigation of a Late Caddo Farmstead in the Red River Valley, edited by Neal L. Trubowitz, pp. 109-170. Research Series No. 23. Arkansas Archeological Survey, Fayetteville.

Skinner, Alan S., Catrina Banks Whitley, Cody S. Davis, Wilson W. Crook, III, and Mark D. Hughston

2014 An Engraved Slate Gorget from the Upper Rockwall Site (41RW2), Rockwall County, Texas. Archeological Journal of the Texas Prairie- Savannah 4(1):68-75.

Stephenson, Robert L.

1949a Archeological Survey of Lavon and Garza-Little Elm Reservoir Report. Bulletin of the Texas Archeological and Paleontological Society 20: 21-62.

1949b A Note on Some Large Pits in Certain Sites near Dallas, Texas. American Antiquity 15(1):5355 .

1952 The Hogge Bridge Site and the Wylie Focus. American Antiquity 17(4): 299-312.

Story, Dee Ann

1990 Culture History of the Native Americans. In The Archeology and Bioarcheology of the Gulf Coastal Plains, by Dee Ann Story, Janice A. Guy, Barbara A. Barnett, Martha D. Freeman, Jerome C. Rose, D. Gentry Steele, Ben W. Olive and Kevin J. Reinhard, pp. 163-366. Research Series No. 38. Arkansas Archeological Survey, Fayetteville.

Suhm, Dee Ann and Alex D. Krieger, with the collaboration of Edward B. Jelks

1954 An Introductory Handbook of Texas Archeology. Bulletin of the Texas Archeological Society 25:1-562.

Suhm, Dee Ann and Edward B. Jelks (editors)

1962 Handbook of Texas Archeology: Type Descriptions. Texas Archeological Society, Special Publications, No. 1, and the Texas Memorial Museum, Bulletin No. 4. Austin.

Valastro, Salvatore, Jr., Frank J. Pearson, and E. Mott Davis

1967 University of Texas Radiocarbon Dates V. Radiocarbon 9:439-453. 
Webb, Clarence H.

1959 The Belcher Mound: A Stratified Caddoan Site in Caddo Parish, Louisiana. Memoirs No. 16. Society for American Archaeology, Salt Lake City.

Weniger, Del

1996 Catalpa (Catalpa bignoniodes, Bignoniaceae) and Bois d'Arc (Maclura pomifera, Moraceae) in Early Texas Records. Sida 17:231-242. 